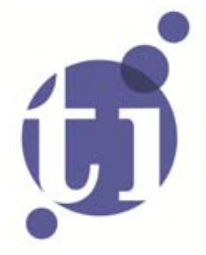

\title{
The Causal Effect of Retirement on Mortality Evidence from Targeted Incentives to retire early
}

\author{
Hans Bloemena,b
}

Stefan Hochguerte/a

Jochem Zweerinka

a Faculty of Economics and Business Administration, VU University Amsterdam, Tinbergen Institute, Netspar;

b IZA, Bonn, Germany. 
Tinbergen Institute is the graduate school and research institute in economics of Erasmus University Rotterdam, the University of Amsterdam and VU University Amsterdam.

More TI discussion papers can be downloaded at http://www.tinbergen.nl

Tinbergen Institute has two locations:

Tinbergen Institute Amsterdam

Gustav Mahlerplein 117

1082 MS Amsterdam

The Netherlands

Tel.: +31(0)205251600

Tinbergen Institute Rotterdam

Burg. Oudlaan 50

3062 PA Rotterdam

The Netherlands

Tel.: +31(0)10 4088900

Fax: $+31(0) 104089031$

Duisenberg school of finance is a collaboration of the Dutch financial sector and universities, with the ambition to support innovative research and offer top quality academic education in core areas of finance.

DSF research papers can be downloaded at: http://www.dsf.nl/

Duisenberg school of finance

Gustav Mahlerplein 117

1082 MS Amsterdam

The Netherlands

Tel.: +31(0)20 5258579 


\title{
The Causal Effect of Retirement on Mortality:
}

\section{Evidence from Targeted Incentives to Retire Early}

\author{
Hans Bloemen ${ }^{a, b}$, Stefan Hochguertel ${ }^{a}$ and Jochem Zweerink ${ }^{a}$ \\ a VU University Amsterdam, Tinbergen Institute, Netspar \\ b IZA Bonn
}

August 12, 2013

\begin{abstract}
This paper identifies and estimates the impact of early retirement on the probability to die within five years, using administrative micro panel data covering the entire population of the Netherlands. Among the older workers we focus on, a group of civil servants became eligible for retirement earlier than expected during a short time window. This exogenous policy change is used to instrument the retirement choice in a model that explains the probability to die within five years. Exploiting the panel structure of our data, we allow for unobserved heterogeneity by way of individual fixed effects in modeling the retirement choice and the probability to die. We find for men that early retirement, induced by the temporary decrease in the age of eligibility for retirement benefits, decreased the probability to die within five years by 2.5 percentage points. This is a strong effect. We find that our results are robust to several specification changes.
\end{abstract}

JEL classification: C26, I1, J26

Keywords: instruments, mortality, retirement

Acknowledgements. This paper is part of the Netspar research theme "Pensions, savings and retirement decisions (II)," subproject "Retirement decisions: financial incentives, wealth and flexibility". We thank Maarten Lindeboom, David Neumark, Ola Vestad and seminar audiences at VU University Amsterdam, the IZA Workshop on Labor Markets and Labor Market Policies for Older Workers and the International Pension Workshop of Netspar for helpful and constructive comments. Correspondence to: Jochem Zweerink, Department of Economics, VU University Amsterdam, Faculty of Economics and Business Administration, De Boelelaan 1105, 1081 HV Amsterdam, The Netherlands. E-mail: j.r.zweerink@vu.nl. 


\section{Introduction}

Understanding the nexus between life cycle labor supply, retirement, and morbidity and mortality is of core interest to policy makers, given observed imbalances in current pension systems in the aging societies of OECD countries. In pension systems that are of the defined benefit type, or that rely on pay-as-you-go social security, ceteris paribus, an increase (decrease) in effective retirement age triggers either higher (lower) aggregate pension contributions or lower (higher) aggregate payouts, if the system is to be held sustainable. The ceteris paribus clause in this statement is important, however, as the discussion held in the academic literature on morbidity and mortality effects of the retirement decision forcefully demonstrates. If longer working lives or later retirement lead to adverse effects on health and even increase the likelihood of dying within a certain horizon, the positive effect of increasing the normal retirement age on the sustainability of pensions is amplified. We find evidence from the Netherlands that is consistent with such an adverse health or mortality effect, albeit from a policy measure that reduced effective retirement age.

The policy change that we rely on became effective in 2005 for certain birth cohorts of civil servants employed by the central government for more than ten years. These individuals were offered the opportunity to retire during the year 2005 , by a temporary reduction of the early retirement (ER) eligibility age. According to our estimates, retirement led to a drop in the probability of men dying within five years after retirement by 42.3 percent, or by 2.5 percentage points. This is a large and significant effect. When we shift the horizon, we find the largest impact of retirement on survival within the first year. Further analysis by primary cause of death suggests that one plausible mechanism may work through the removal of stress-related factors associated with demanding work as we find significant effects on dying from a stroke.

Identifying the causal impact of retirement on morbidity or mortality is challenging, in particular as the only research design that allows doing so has to rely on observational data on health and life outcomes. The latter, in turn, calls for an approach that helps controlling the selection into retirement since bad health typically triggers retirement and subsequently mortality. Our approach uses the described policy variation as an instrument for retirement status in explaining the probability of dying from both observable characteristics and unobservables. Importantly, we rely on an individual fixed effects specification for the latter. We employ a difference-in-difference specification on data for civil servants, controlling for year fixed effects and nonlinear age effects. We use a difference-in-difference-in-difference specification for data on civil servants and workers employed in other sectors. Our difference-in-difference-in-difference specification controls for year 
fixed effects, nonlinear age effects and differences in year effects and nonlinear age effects between civil servants and other workers. The probability to die within five years is the dependent variable in our models. We choose the time horizon of five years since we are interested in the effect of early retirement on mortality in the relatively short run. We do not want to estimate the effect of early retirement on mortality in too short a run, because retirement may affect the probability to have diseases that may lead to death within several years. The choice of evaluation horizon several years ahead for the probability to die is limited by the time length of our panel data.

There is a range of related papers that investigate the effect of retirement on morbidity or health. Papers that use age-specific retirement rules provide very inconclusive findings, however. Charles (2004), Hemingway et al. (2003), Coe and Lindeboom (2008), Neuman (2008), Coe and Zamarro (2011), Blake and Garrouste (2012a, b) find that retirement has a positive impact on health. ${ }^{1}$ Kuhn et al. (2010), Behncke (2012) and Dave et al. (2008) find a negative impact of retirement on health. ${ }^{2}$ What is not entirely understood in this literature is the way in which retirement changes morbidity and mortality outcomes. In particular, direct evidence is scarce.

Our contribution to this literature is fourfold. First, our policy variation delivers a natural experiment that we exploit to construct a strong and exogenous instrument. Becoming eligible for retirement benefits due to the ER eligibility age for civil servants being reduced substantially increased the probability to retire. Eligible civil servants only got to know about the decrease in the ER eligibility age one year before they became eligible, so anticipation of early retirement can arguably be ruled out. Second, we focus on mortality instead of health outcomes, an event which is distinctly and objectively observed and does not raise issues of interpretation or subjectivity. Third, we use administrative data covering the entire population, and thus follow a large number of individuals over a number of years. As the mortality register essentially provides complete and measurement error-free information, we do not need to worry about selective attrition as an alternative reason for not being recorded in the data anymore. Fourth, the unrivalled comprehensive database puts us in a position to split the analysis by cause of death at a very detailed level and we can thus obtain additional insights into the channels through which the positive effect of retirement on survival (health) comes about.

\footnotetext{
${ }^{1}$ Blake and Garrouste (2012b) use mortality as the outcome variable. They find a negative effect of later retirement on the probability to die within four years.

${ }^{2}$ Kuhn et al. (2010) use mortality as the outcome variable. They find a positive effect of early retirement on the probability to die till age 67.
} 
The rest of the paper is organized as follows. Section 2 reviews related literature. Section 3 describes the institutional setting, including the policy shift decreasing the ER eligibility age. Section 4 discusses the data and provides insightful descriptives. Section 5 delineates the research design we use to identify the causal effect of retirement on mortality outcomes, and Section 6 presents the empirical results. Section 7 concludes.

\section{Literature review}

The theoretical impact of retirement on mortality is not clear-cut. There are scores of papers in the medical, gerontological and related disciplines that document heterogeneous patterns and multifaceted potential pathways between retirement and health. Apart from physiological and psychological processes that govern health, life style aspects are often discussed. Since individual choices for both retirement and health behaviors reflect important trade-offs that people face, we think it is useful to start with briefly reviewing the main implications of the standard economic approach.

Any discussion in the economic literature sees retirement as a one-off, irreversible event. As individuals with a poorer health are more likely to die than individuals with a better health, it seems reasonable to assume that the impact of retirement on mortality runs through health. Early retirement can have an impact on health through several mechanisms. Grossman (1972) provides a framework for analyzing the causal relation between retirement and health. He models health as a dual investment and consumption good. A healthy individual with fewer sick days is more productive and more able to work than a less healthy individual. As health raises an individual's productivity and ability to work, the agent has an incentive to invest in his or her health. Health is also a consumption good and directly features as an argument in the utility function. When the individual retires, costs and benefits from health change. On the benefits side, the incentive to invest in health to raise productivity and ability to work disappears after retirement. ${ }^{3}$ The utility that is derived from health in a direct way may change after retirement. On the costs side, incentives to invest in health may be different after retirement than before retirement. As an individual has more leisure time after retirement, the time cost of investing in health is lower. As a result, an individual may, for instance, physically exercise more frequently or go to the doctor sooner and be diagnosed and receive

\footnotetext{
${ }^{3}$ Grossman does not consider productivity in household production. Individuals may value being productive in household production before and after retirement, giving an incentive to invest in health before and after retirement.
} 
medical treatment when he or she has some physical or mental complaints. ${ }^{4}$ The sign of the net effect of retirement on health in the Grossman model is unclear and depends on how retirement changes the personal valuation of the costs of investment in health and the benefits from health (Dave et al., 2008).

In empirical research, of course, health may act as a confounding variable. For instance, early studies by Bazolli (1985) and Dwyer and Mitchell (1999) have found that health has a negative impact on the probability to retire early. The literature on the impact of retirement on health addresses the endogeneity of retirement status to health and mortality outcomes using a large range of different identification strategies. ${ }^{5}$ Table 1 summarizes the literature. The focus in the literature has shifted in recent years to studies that employ policy variation in order to measure the effect of interest in a natural experiment setting. The definition of treatment and control groups remain context specific, however. Charles (2004), Neuman (2008), Coe and Lindeboom (2008), Kuhn et al. (2010) and Blake and Garrouste $(2012 a, b)$ instrument retirement status by retirement incentives that were age and/or year specific. Coe and Zamarro (2011) and Behncke (2012) address the endogeneity of retirement status by using institutions as an exogenous shifter of the probability to retire. Many of these studies rely on subjective survey information from the U.S. Health and Retirement Study (HRS).

Charles (2004) uses three sources of variation in the probability to retire to instrument retirement status: age specific retirement incentives, a labor force participation enhancing change in the US Social Security system and the elimination of mandatory retirement rules. Using HRS, Survey of Asset and Health Dynamics among the Oldest Old (AHEAD) and National Longitudinal Survey of Mature Men (NLS-MM) data for men, the author finds that retirement has a positive impact on psychological well-being. Neuman (2008) uses age specific retirement incentives as an instrument for retirement status. The author uses data from the HRS for men and women and finds that retirement improves subjective health, although retirement does not affect physical functioning in daily activities, mental health or the probability to have a chronic disease. The age specific retirement incentives used as an

\footnotetext{
${ }^{4}$ Midanik et al. (1995) find that workers physically practice more once they retire. Boaz and Muller (1989) and Roos and Shapiro (1982) do not find evidence for workers receiving more ambulatory services from physicians once they retire.

${ }^{5}$ The literature on the effect of retirement on health is closely related to the literature on the effect of job displacement on health. In that literature, job displacement is considered to be a stressful event, and the effect of job displacement on health or mortality is considered to run through stress. Sullivan and von Wachter (2009) find for data on older workers that job displacement has a strong and negative effect on mortality in the first year after job displacement. Browning et al. (2006) and Salm (2009) do not find an effect of job displacement on health.
} 
instrument by Charles (2004) and Neuman (2008) concerned expected decreases in generosity of retirement benefits for different age categories across time. The decreases in generosity of retirement benefits have induced workers to postpone retirement. As the decreases in generosity of retirement benefits were announced years ahead, workers may have anticipated them. Workers who decided to postpone retirement because of the decreased generosity of retirement benefits may have reduced the number of hours worked or may have started to live healthier, so that they would have been better able to continue working. Anticipation may have biased the treatment effect towards zero.

Coe and Lindeboom (2008) is an interesting paper since it addresses the endogeneity of retirement status by using retirement windows as an instrument for retirement status. Early retirement windows are incentives that promote retirement at a specific time. Employers determine to whom these incentives are offered. We shall exploit a similar set-up. With HRS data for men, Coe and Lindeboom find that retirement increases self-reported physical and mental health temporarily. The authors also find that retirement improves health of highly educated workers. The authors find no effect of retirement on mortality. As early retirement windows may be offered to workers with certain health characteristics, the results may be biased.

Blake and Garrouste (2012a, b) use a policy change in France that provides incentives to retire and affects specific birth cohorts of private sector workers as a source of exogenous variation in retirement age. The authors use data on older workers from the 1999 and 2005 wave of the French Baromètre Santé survey. Blake and Garrouste (2012a) estimate the treatment effect using two methods. First, they use the reform as an instrument for retirement age. In their second approach, the authors perform a before-after difference-in-difference estimation. The control group consists of public sector workers who are unaffected by the reform. The treatment group consists of private sector workers who are affected by the reform. The instrumental variable and difference-indifference estimates indicate a positive impact of retirement age on physical and social health for men and women. Blake and Garrouste (2012b) estimate the treatment effect employing an instrumental variable approach and use data for men only. The authors use mortality within four years as the outcome variable. They find that retiring one year later increases the probability to die with 1.5 percentage points. This is equivalent to a decrease in life expectancy at age 64 by 1.68 months.

Kuhn et al. (2010) use a regional change in unemployment insurance (UI) rules in Austria as an instrument for the difference between the statutory retirement age and the actual retirement age. UI can be used in Austria as a pathway to (early) retirement. The change in UI rules allowed workers 
in eligible regions to withdraw from the workforce up to 3.5 years earlier than those in non-eligible regions. Using administrative data for male and female blue-collar workers, the authors find that for every year a male worker retires earlier, the probability to die before age 67 increases by 2.4 percentages points or 13 percent. Hence, if a male worker retires 3.5 years earlier, the probability to die before age 67 is increased by 8.4 percentage points or 46.9 percent. Especially cardiovascular diseases are found to be responsible for the increase in the probability to die. One of the plausible channels that emerges from the analysis is that alcohol use and also smoking change upon retirement and eventually cause ill health. The authors do not find an effect of early retirement on mortality for female workers.

Coe and Zamarro (2011) employ a fuzzy regression discontinuity design, using the eligibility age for public old-age benefits as the point of discontinuity in the probability to retire. The authors use single cross-section data from eleven European countries for men only. The data are collected in the Survey of Health, Aging and Retirement in Europe (SHARE). The authors find a positive impact of retirement on general health for workers aged 65 . The authors do not find an effect for workers younger than age 65 . Behncke (2012) exploits the eligibility age for public old-age pension benefits as a source of exogenous variation in retirement status. The author employs propensity score matching as well as an instrumental variable approach. For propensity score matching, workers who reached the eligibility age for public old-age pension benefits are matched to similar workers who did not reach the eligibility age for public old-age pension benefits yet. For the instrumental variable approach, the author uses the eligibility age for public old-age pension benefits as an instrument for retirement status. Behncke controls for anticipation of retirement by adding expectations about future work and health as control variables in her analyses. Using data from the English Longitudinal Study of Ageing (ELSA), the author finds that retirement increases the probability of being diagnosed with a chronic condition such as a heart disease or cancer for men and women.

Hemingway et al. (2003) and Dave et al. (2008) use alternative approaches to address the endogeneity of retirement status. Dave et al. (2008) try to limit the endogeneity bias by only considering workers who were healthy before retirement. They estimate models in which retirement status and health status are mutually dependent. The authors use data from the HRS and AHEAD. They find that retirement induces a six percent increase in illnesses and a six to nine percent increase in depressions for men and women. Hemingway et al. (2003) estimate the impact of retirement on health, using data for male and female civil servants from the Whitehall II study. Some particular groups of civil servants were allowed to retire later than the regular mandatory retirement age. The authors compare changes in health of unaffected civil servants retiring at the mandatory 
retirement age with those of affected civil servants retiring later. Important here is that cases of illhealth retirement are excluded from the sample. The authors find no effect of retirement on physical health for men and women and a positive effect of retirement on mental health for men and women in higher socioeconomic status groups.

\section{Institutional background and policy change}

We follow the recent literature that exploits quasi-experimental variation afforded by changes in retirement rules. In particular, we shall focus on targeted incentives to retire early that became available to a group of civil servants in the Netherlands. The Dutch retirement system foresees in retirement at the standard age (for both men and women) of 65 . Actual average ages of entering retirement have been considerably lower, however, due to the widespread use of early retirement arrangements in virtually all sectors of the economy. ${ }^{6}$

The Dutch pension system rests on three pillars (Bovenberg and Meijdam, 2001). The first pillar is the public old-age pension, which is financed on a pay-as-you-go basis. The second pillar consists of occupational pensions, which are funded. The third pillar consists of private provisions. We study the period around 2005. At that time most occupational pension funds offered early retirement arrangements. The public sector pension fund offered arrangements for early retirement as of the ages 61 or 62 onwards. We use a temporary decrease in the ER eligibility age for civil servants as a source of exogenous variation to estimate the impact of early retirement on the probability to die within five years.

In April 2004, a temporary decrease in ER eligibility age for civil servants was announced. We refer to the temporary decrease in the ER eligibility age for civil servants as 'the early retirement arrangement' in the sequel. Due to a reorganization of the central government, employers being part of the central government were allowed to offer certain civil servants additional possibilities for early retirement in the year 2005. Employers were only allowed to offer early retirement if this would prevent the forced layoff of another civil servant. ${ }^{7}$ The early retirement arrangement offered gross retirement benefits that could be up to 70 percent of workers' final wage, which corresponds to the benefit level in other ER programs. ${ }^{8}$

\footnotetext{
${ }^{6}$ A description of the Dutch pension system and existing early retirement arrangements for civil servants can be found in the appendix of this paper.

${ }^{7}$ Forced layoff refers to forced layoff due to reorganization.

${ }^{8}$ The replacement rate depended among others on the birth date of an individual.
} 
Civil servants faced several eligibility criteria for participation in the early retirement arrangement. First, they had to be at least 55 at the moment of early retirement. Second, they needed to have been employed as a civil servants continuously during the ten years prior to early retirement. This requirement is of importance for our study, as it prevents self-selection of workers who would like to retire early into the public sector. Civil servants were required to have contributed to the public sector pension fund continuously during the ten years prior to early retirement. ${ }^{9}$ Employers were allowed to offer participation in the early retirement arrangement until 1 January 2005 and participating civil servants were not allowed to retire later than 1 December 2005. Participating civil servants were entitled to early retirement benefits until age 65 with a maximum duration of eight years. Civil servants aged 57 or older at the moment of early retirement were thus entitled to retirement benefits for the whole period until normal retirement at age 65 . Civil servants born before 1 January 1948 could continue accruing pension claims at a rate of 50 percent at the expense of the employer for a maximum of four years. Civil servants born on or later than 1 January 1948, i.e. civil servants who were aged 55-57 in 2005, did not have this opportunity. The early retirement arrangement was thus very attractive for civil servants aged 58 and older, ${ }^{10}$ less attractive for civil servants aged 57 and even less attractive for civil servants aged 55 or 56.

\section{Data}

We use Dutch administrative data for the period 1999-2010. The data are administered by Statistics Netherlands. We have access to data on mortality, hospital stays, and job and personal characteristics originating from various administrative sources that can be linked with a personal identifier. ${ }^{11} 12$ The mortality file provides information such as year and primary (and secondary) cause(s) of death. The hospital stay file provides for every hospital stay information such as the start and end date of the stay, the reason for the stay and where the patient went after being released from the hospital. The job characteristics file provides information on all jobs any individual has been

\footnotetext{
${ }^{9}$ Interruption of employment and pension contribution of at most two months was allowed, although interruption of employment and pension contribution in the half year prior to early retirement would have led to loss of eligibility.

${ }^{10}$ The offer of early retirement through the particular ER window was "an offer they could not refuse" for this group of individuals.

${ }^{11}$ The original file names are Doodsoorzaken (1999-2010), Landelijke Medische Registratie (LMR, 1998-2004), SSB Banen (1999-2008), SSB Personen (1999-2005) and PARTNERBUS (2010).

12 Statistics Netherlands only provides data that are administered by governmental institutions. These data provide only limited information. Moreover, the data that are administered are not always administered for the years we are interested in. Data on financial wealth, for instance, are not available for the years of study. Hospital stays data are incomplete after 2005 , so that it is not possible to estimate the effect of early retirement on alternative health measures created from hospital data.
} 
employed in during 1999-2005. For every job, both start and end date, the industry code and the annual wage are available. ${ }^{13}$ The personal characteristics file contains information on demographic characteristics such as nationality, marital status, birth year and birth month. The personal characteristics file also includes a partner identifier that allows us to link partners to each other. The files we use cover all residents registered with Dutch municipalities.

For our analysis we select observations on individuals aged 53-60 during 1999-2005. We exclude observations on individuals without a Dutch citizenship during 1999-2005. We also exclude observations for which the relevant individual has not been continuously employed for the ten years prior to January $1^{\text {st }}$ of the year of observation. We make this selection, as one of the eligibility criteria for participation in the early retirement arrangement for civil servants is that civil servants have been continuously employed as a civil servant for the ten years prior to early retirement. For the same reasons, observations on workers who switched between the public sector and any other sector are excluded from the analysis as well. Observations on workers who stayed in the hospital somewhere between 1998 and retirement are also excluded from our analysis. ${ }^{14}$ By dropping the observations on workers who stayed in the hospital before retirement, we aim to limit the endogeneity of retirement status to health. We also drop observations for the years after the year in which a worker has retired. ${ }^{15}$ We use about 155,000 observations on male civil servants and about 34,000 observations on female civil servants.

Table 2 shows descriptive statistics for civil servants and workers employed outside the public sector. Age is measured on December $31^{\text {st }}$ of the respective year. The variable married takes value 1 if a worker had a partner in the year of observation, 0 otherwise. ${ }^{16}$ Lagged wage income indicates the total wage income a worker earned in the year prior to the year of observation. Lagged wage income is measured in thousands of deflated Euros. We only have a limited number of variables at our disposal that we can use as controls. Because of this, the individual fixed effects that we control for in our instrumental variable model are expected to be important in explaining retirement status and the probability to die within five years. One might think in the first place of effects due to year of birth, education, or chronic health conditions. In addition, the fixed effects also correct for time-

\footnotetext{
${ }^{13}$ The industry code for the central government is 7511 according to the Standaard Bedrijfsindeling 1993 (SBI '93) classification.

14 If a worker was hospitalized but did not retire in 1999-2005, all observations on this worker are dropped.

${ }^{15}$ We assume that individuals do not work after retirement, though we can only observe employment state until January $1^{\text {st }}, 2009$. This is discussed in more detail later in this section.

${ }^{16}$ Having a partner includes being married and having a registered partnership, but excludes cohabitation without being married or without having a registered partnership. Registered partnership refers to partnerships enjoying legal status similar to marriage.
} 
constant heterogeneity that remains unobserved in administrative data, such as preference parameters determining choices.

The average age of individuals in our dataset is 56 , which indicates that relatively young individuals are relatively overrepresented in our dataset. ${ }^{17}$ Male civil servants are in general comparable to male workers employed in other sectors. Female civil servants clearly differ from female workers employed outside the public sector. Wage income in the year prior to the year of observation was higher for female civil servants than for female workers employed outside the public sector. Moreover, female civil servants had a lower probability to have a partner than women employed outside the public sector. Table 2 also shows that the control group is similar in marital status and lagged wage income to the treatment group. The control group includes civil servants aged 53-54 in 2005 , i.e. those civil servants who could not be offered early retirement. The treatment group includes civil servants aged 55-60 in 2005, i.e. those civil servants who could be offered early retirement. Differences in marital status and lagged wage income between workers in the control group and those of the same age employed in other sectors are similar to those between workers in the treatment group and those of the same age employed in other sectors.

The group of civil servants that could be offered early retirement due to the temporary decrease in the ER eligibility age consisted of civil servants working for the central government. The sector in which individuals work is identified by an industry code. Most civil servants working for the central government were assigned the same industry code as some groups of civil servants who were not working for the central government. Hence, we cannot precisely identify the group of civil servants working for the central government. When we refer to civil servants later on in this paper, it should be kept in mind that we mean central government civil servants including a group of other civil servants who were ineligible for the early retirement arrangement of interest. ${ }^{18}$ Another data issue is that we do not observe to which civil servants early retirement was offered. We can thus not observe whether an eligible civil servant rejected the early retirement offer or whether a civil servant with characteristics of an eligible civil servant did not retire early because he or she was not offered the early retirement arrangement. Thus, the "treatment" group we define in our data is somewhat wider than the "true" treatment group. ${ }^{19}$ We also do not know whether there was selection in offering the early retirement arrangement to some specific groups only, e.g. to workers

\footnotetext{
${ }^{17}$ This is partly the result of dropping observations after having transitioned into retirement.

${ }^{18}$ This issue may lead to our estimates of the impact of the early retirement arrangement on retirement constituting lower bounds of the real impact, and likewise to possible bias of the estimates of the impact of early retirement on the probability to die within five years towards zero.

${ }^{19}$ We do not know how much larger the treatment group is than the "true" treatment group.
} 
who were relatively less productive or were relatively often ill. If there would have been selection, this could bias our results or could at least force us to reinterpret our results. The final data issue concerns the absence of information on whether individuals receive retirement benefits. We define retirement as having exited a job and not having started working again before January $1^{\text {st }}, 2009$.

Figures $1 \mathrm{a}$ and $1 \mathrm{~b}$ show that the probability that male and female civil servants die within five years increases across age for several birth cohorts. There are birth cohorts that follow different patterns as well. Civil servants who were born relatively long ago have in general a higher probability to die within five years than civil servants with the same age who were born relatively recently. The observed patterns are not smooth and do not show consistent patterns for all birth cohorts. ${ }^{20}$ We consult mortality data on the whole population from Statistics Netherlands to get a better view on mortality patterns across age and birth cohorts. Figures $2 a$ and $2 b$ show that the probability to die within five years for the whole Dutch population increases smoothly across age and decreases smoothly across birth cohorts. ${ }^{21}$ Observed probabilities are higher than those observed for civil servants. This is intuitive, as individuals employed as a civil servant may have a relatively modest probability to die within five years compared to, for instance, individuals who do not work. The probabilities to die within five years are higher for men than for women. The age gradient in the probability to die within five years is higher for men than for women as well.

\section{Methodology}

We employ an instrumental variable approach to estimate the impact of early retirement on the probability to die within five years. We instrument the retirement choice by dummies for the ages for which civil servants are eligible for the early retirement arrangement interacted with a dummy for the year of the policy change and a dummy for being a civil servant. We estimate a model using a difference-in-difference specification for civil servants and a model using a difference-in-differencein-difference specification for civil servants and workers employed outside the public sector. In the model using the difference-in-difference specification, the source of exogenous variation in retirement status is the age in $2005 .{ }^{22}$ In the model using the difference-in-difference-in-difference specification, being or not being a civil servant in 2005 is the additional source of exogenous variation. Being or not being a civil servant is exogenous here, because we only include observations where the relevant individual has been either continuously employed as a civil servant for the ten

\footnotetext{
${ }^{20}$ This is in combination with the probabilities to die within five years being low.

${ }^{21}$ The cohort of individuals born in 1945 shows a slightly deviating pattern for the ages 53-57.

${ }^{22}$ Age in 2005 determines eligibility for the ER arrangement, see Section 3.
} 
years prior to the year of observation or continuously employed outside the public sector for the ten years prior to the year of observation.

We use civil servants aged 53 or 54 in 2005 as the control group and civil servants aged 55-60 in 2005 as the treatment group. ${ }^{23}$ Our models control for individual fixed effects. As men and women have different retirement patterns and remaining life expectancies, we estimate our model for men and women separately. The treatment effect we estimate is the Local Average Treatment Effect (LATE), i.e. the effect of early retirement on the probability to die within five years for those who are induced to retire early by variation in the instruments.

\subsection{Instrument validity}

The instrument we use is valid if two conditions are satisfied. First, the instrument has an impact on the probability that individuals receive the treatment. Second, the instrument does not correlate with unobserved factors having an impact on the outcome. The instruments we use are dummies for eligibility for retirement benefits due to the temporary decrease in the ER eligibility age for civil servants in 2005.

Figures $3 a$ and $3 b$ show retirement rates for male and female civil servants. Retirement rates for civil servants aged 58-60 were substantially higher in 2005 than in other years. Retirement rates for civil servants aged 56-57 and female civil servants aged 55 were higher in 2005 than in other years as well. Retirement rates for civil servants aged 53 and 54 were similar in 2005 as in other years. This is in line with the incentives provided by the introduction of the early retirement arrangement and suggests that the early retirement arrangement for civil servants induced civil servants to retire early. ${ }^{24}$

We do not have reasons to expect that the introduction of the early retirement arrangement had a direct impact on the probability to die within five years. To our knowledge, there were no events in 2005 or in the five years after that shocked the probability to die within five years for civil servants aged 55-60 in 2005 particularly, other than the reform we study. We also do not have reasons to expect that our instruments are correlated with unobserved factors that influenced the probability

\footnotetext{
${ }^{23}$ As we estimate a fixed effects model, observations on individuals that we observe for only one year are not used. As civil servants aged 53 in 2005 are observed for only one year, observations on these civil servants are not used. This implies that our control group consists only of civil servants aged 54 in 2005.

${ }^{24}$ There were several other pension related policy changes around the period under review. These policy changes and their possible effects on retirement rates are discussed in the Appendix.
} 
to die within five years. Unobserved factors that are expected to have influenced the probability to die within five years may include the unobserved level of health, health-related behavior, ${ }^{25}$ the number of hours worked and associated stress levels. If retirement induced by the early retirement arrangement was anticipated, the number of hours worked and health-related behavior may have been correlated with the introduction of the early retirement arrangement. However, the introduction of the early retirement was only announced in April 2004 and employers decided only later in 2004 whether they would offer a civil servant the early retirement arrangement. As civil servants were only informed late during 2004 whether they were offered the early retirement arrangement, we do not expect anticipation of early retirement to be an issue. Another possible concern is that the jump in retirement rates for civil servants in 2005 is driven by factors other than the introduction of the early retirement arrangement for civil servants in 2005. Figures $4 \mathrm{a}$ and $4 \mathrm{~b}$ show that retirement rates for workers aged 55-60 employed outside the public sector were not higher in 2005 than in other years. This indicates that the difference in retirement rates for civil servants aged 55-60 between 2005 and other years is not caused by factors that shifted retirement rates of the entire workforce in 2005.

The validity of the difference-in-difference-in-difference approach depends on the justification of the common trend assumption. The common trend assumption implies that the probability to die within five years and the probability to retire for civil servants follow trends similar to those of workers employed outside the public sector. Figures $5 a$ and $5 b$ show that the probabilities to die within five years for workers employed outside the public sector follow similar patterns as those for civil servants for only several birth cohorts. We have discussed above that retirement rates of civil servants aged 59 or younger follow similar patterns as those of workers employed outside the public sector. As the patterns for the probability to die within five years across age for civil servants differ from those for workers employed in other sectors, the common trend assumption is possibly violated. Nevertheless, the approach is valuable, as it provides estimates based on imposing a rather smooth probability to die within five years across age patterns on civil servants.

\subsection{Model specification}

We estimate the LATE using a two-stage-least-squares fixed effects instrumental variable model. In the first stage, retirement status is estimated and in the second stage, the impact of predicted retirement on the probability to die within five years is estimated. Our instrumental variable model has as advantage that it controls for time-invariant unobserved heterogeneity and allows the

${ }^{25}$ Including getting diagnosed and treated. 
individual fixed effects to be correlated with observed characteristics. We use a difference-indifference specification for our model and estimate it for civil servants only. We control for year effects and for differences in the probability to die within five years and the probability to retire across age. The first stage of the difference-in-difference variant of our model is specified as follows:

$$
R_{i t}=e_{0}+\sum_{j=1999}^{j=2004} b_{j} D_{j t}+\sum_{k=2}^{k=3} c_{k} A_{k i t}+\sum_{l=55}^{l=60} d_{05, l} D_{05, t} E_{l i t}+g M_{i t}+h_{i t-1}^{\prime} \vartheta+e_{i}+v_{i t}
$$

where $R_{i t}$ is a dummy that is 1 if individual $i$ is aged 55 or older in year $t$ and individual $i$ retired in year $t . R_{i t}$ is 0 otherwise. $D_{j t}$ is a year dummy that is 1 in year $j$ and 0 otherwise. $A_{k i t}$ denotes the difference between the age of individual $i$ in year $t$ and 53 , taken to the $k$ th power. ${ }^{26} E_{\text {lit }}$ is an age dummy that is 1 if individual $i$ reaches age $/$ in year $t$ and 0 otherwise. $M_{i t}$ is a dummy that is 1 if individual $i$ has a partner in year $t$ and 0 otherwise. $h_{i t-1}$ includes lagged wage income. $e_{i}$ is an individual fixed effect. $v_{i t}$ is an error term. $e_{i}$ is allowed to be correlated with all covariates.

The second stage is specified as follows:

$$
Y_{i t}=\alpha_{0}+\sum_{j=1999}^{j=2004} \gamma_{j} D_{j t}+\sum_{k=2}^{k=3} \delta_{k} A_{k i t}+\beta M_{i t}+h_{i t-1}^{\prime} \varphi+\omega \hat{R}_{i t}+\alpha_{i}+u_{i t}
$$

where $Y_{i t}$ is a dummy that is 1 if individual $i$ dies within five years after year $t$ and 0 otherwise. $\omega$ indicates the LATE. $\alpha_{i}$ is allowed to be correlated with all covariates. $\alpha_{i}$ and $e_{i}$ are also allowed to be correlated. $u_{i t}$ and $v_{i t}$ are allowed to be correlated as well.

We also estimate the LATE using a difference-in-difference-in-difference specification for data on civil servants and workers employed outside the public sector. We do so, because the retirement and mortality patterns of workers employed outside the public sector, shown in Figures 4 and 5 , are smoother than those for civil servants shown in Figures 1 and 3 . This is due to the relatively modest number of observations for civil servants. The first stage of the instrumental variable model for the entire workforce is specified as follows:

$$
\begin{aligned}
& R_{i t}=e_{0}+\sum_{j=1999}^{j=2004} b_{j} D_{j t}+\sum_{k=2}^{k=3} c_{k} A_{k i t}+\sum_{l=55}^{l=60} d_{05, l} D_{05, t} E_{l i t}+\sum_{j=1999}^{j=2004} b_{j c} D_{j t} C_{i t}+ \\
& h_{05 n c} D_{05, i t} N C_{i t}+\sum_{k=2}^{k=3} c_{k c} A_{k i t} C_{i t}+\sum_{l=55}^{l=60} d_{05 c, l} D_{05, t} E_{l i t} C_{i t}+g M_{i t}+h_{i t-1}^{\prime} \vartheta+e_{i}+v_{i t}
\end{aligned}
$$

where $C_{i t}$ is a dummy that is 1 if individual $i$ is a civil servant in year $t$ and 0 otherwise. $N C_{i t}$ is a dummy that is 1 if individual $i$ works outside the public sector in year $t$ and 0 otherwise. The difference between (3) and (1) is the inclusion of the interactions between the age variables and the dummy for being a civil servant, the interactions between year dummies and the dummy for being a

\footnotetext{
${ }^{26}$ We do not include $A_{1 i t}$ in our models. Including $A_{1 i t}$ is not possible due to multicollinearity caused by the presence of the year dummies.
} 
civil servant, and the interaction between the dummy for 2005 and the dummy for not being a civil servant. Moreover, the instruments in (1), i.e. the interactions between the dummy for 2005 and the age dummies, are interacted with the dummy for being a civil servant in (3). As the difference-indifference specification does, the difference-in-difference-in-difference specification controls for nonlinear age effects and year fixed effects. In addition, the difference-in-difference-in-difference specification controls for differences in nonlinear age effects and year fixed effects between civil servants and workers employed outside the public sector.

The second stage of the instrumental variable model for the entire workforce is specified as follows:

$$
\begin{aligned}
& Y_{i t}=\alpha_{0}+\sum_{j=1999}^{j=2004} \gamma_{j} D_{j t}+\sum_{k=2}^{k=3} \delta_{k} A_{k i t}+\sum_{j=1999}^{j=2004} \gamma_{j c} D_{j t} C_{i t}+\sum_{k=2}^{k=3} \delta_{k c} A_{k i t} C_{i t}+ \\
& \kappa_{05 n c} D_{05, t} N C_{i t}+\beta M_{i t}+h_{i t-1}^{\prime} \varphi+\omega \hat{R}_{i t}+\alpha_{i}+u_{i t}
\end{aligned}
$$

The differences between (4) and (2) are essentially the same as those between (3) and (1).

\section{Results}

\subsection{The uninstrumented case}

We instrument retirement status because of the potential endogeneity of retirement status to health. Table 3 shows the difference-in-difference and difference-in-difference-in-difference estimates with individual fixed effects for when retirement is not instrumented, i.e. the estimates of $\omega$ in (2) and (4) with retirement status $R_{i t}$ instead of predicted retirement status $\hat{R}_{i t}$. The coefficient estimates on retirement are positive and significant at the five percent level for men. The differencein-difference-in-difference coefficient estimate for women is positive and significant as well. The difference-in-difference coefficient estimate for women is not significant. For men, the difference-indifference coefficient estimate indicates that retirement is associated with a 0.6 percentage point, or 16.7 percent, higher probability to die within five years. The difference-in-difference-in-difference estimate for men is 0.4 percentage point, or 9 percent, and for women 0.1 percentage point, or 6.1 percent respectively. If retirement status would not be endogenous to health, we would expect the coefficient estimate on retirement status in these uninstrumented fixed effects models to be similar to those of the instrumental variable models with fixed effects. 


\subsection{Instrumental variable estimates}

Table 4 shows the instrumental variable fixed effects estimates using the difference-in-difference and difference-in-difference-in-difference specifications. ${ }^{27}$ The estimates using the difference-indifference specification show that retirement induced by the early retirement arrangement decreased the probability to die within five years by 2.5 percentage points, or 42.3 percent, for men. Blake and Garrouste (2012b) find effects of a similar order of magnitude. Kuhn et al. (2010) also find large effects for blue-collar workers, however of the opposite sign. This suggests that the absolute magnitude of the effect we find is not particularly striking. The LATE for women is not significant at the ten percent level. The difference-in-difference-in-difference instrumental variable estimates are very similar to the difference-in-difference instrumental variables estimates.

The F statistics for the relevance of the instruments in the first stage show that our instruments are relevant at the one percent significance level. The coefficients on the instruments in the first stage are positive, indicating that the introduction of the early retirement arrangement did induce eligible civil servants to retire. The J statistics for exogeneity of our instruments show that the null hypothesis that our instruments are exogenous cannot be rejected at the ten percent significance level for men. However, the J statistics show that instruments suffer from endogeneity for women. ${ }^{28}$ We can thus not interpret the LATE estimate for women as a causal effect.

\subsection{Causes of death}

Specific causes of death may be related to working or being retired. For instance, if working would impose a high risk on accidents, the effect of retirement on mortality may run through accidents. This mechanism would then be revealed by considering mortality due to accidents. To get more insight into the mechanism through which early retirement affects mortality, we estimate the instrumental variable models in (1)-(2) and (3)-(4) using a dummy for dying within five years due to a specific cause as a dependent variable. The causes of death for which we estimate our models are grouped according to the $10^{\text {th }}$ Revision of the International Statistical Classification of Diseases and Related Health Problems (ICD). The ICD is a health care classification system by the World Health Organization (WHO, 2010). The ICD provides diagnostic codes for classifying diseases. The diseases

\footnotetext{
${ }^{27}$ The probability to die within five years is negative in lagged wage income, positive in lagged health and positive in age.

${ }^{28}$ The rejection of the null hypothesis that the instruments are exogenous is probably the result of the small number of observations for female civil servants. As the number of civil servants retiring in 2005 and die within five years after 2005 is small, fatalities unrelated to retirement can easily threaten the exogeneity of the instruments.
} 
are grouped into 22 categories, so called chapters. We estimate the causes of death for the chapters, or, in case of the frequent causes of death cancer and diseases of the circulatory system, subchapters, so called blocks. Chapters counting less than ten observations on fatalities are merged in the category "Other diseases".

Tables 5 and 6 show that the LATEs of early retirement on mortality due to almost all causes of death are negative. This indicates that the effect of early retirement on mortality does not run mainly through a particular cause of death, but rather through many causes of death. Most LATEs are not significant. This is due to the small number of fatalities due to specific causes of death. The LATEs of early retirement on mortality due to stroke (cerebrovascular diseases), liver diseases (diseases of the digestive system) and accidents (external causes of morbidity and mortality) are exceptions. They are negative and significant at successively the one, one and ten percent level. Early retirement has a negative LATE of 0.5 percentage point or 12.7 percent on the probability to die within five years due to stroke. This implies that there are 11 fatalities due to stroke less within five years because workers were induced to retire by the early retirement arrangement. This is a large number as there were only 2,348 workers induced to retire early. Stroke as a cause of death is interesting in the context of this paper, since life style can have a significant impact on the probability of dying from stroke. Hypertension, diabetes, obesity, alcohol use, smoking and lack of physical exercise are among the modifiable risk factors for stroke. ${ }^{29}$ Hypertension is the most important modifiable risk factor for stroke. Risk factors for hypertension include obesity, smoking, alcohol consumption and lack of physical exercise (Appel et al., 2006, Begg et al., 2006), so obesity and smoking pose a direct and indirect threat for contracting stroke. Stress may result in hypertension as well (Kaplan and Nunes, 2003).

\subsection{Distribution of treatment effects across time horizons}

We have estimated the effect of early retirement induced by the introduction of an early retirement arrangement on the probability to die within five years. Table 7 shows the estimates for the effect of early retirement on the probability to die within fewer years. Though insignificant at the five percent level, the coefficient on the effect of early retirement on the probability to die within one year is large and negative in size. Differences between the effect of early retirement on the probability to die within one and two, two and three, and three and four years are positive and relatively modest in size. This indicates that the effect of early retirement on dying during each of the second to fourth

\footnotetext{
${ }^{29}$ Risk factor indicates a factor that is correlated with the prevalence of a disease. There is not necessarily a causal relation between a risk factor and the prevalence of a disease.
} 
year are negative and relatively modest in size compared to the effect of early retirement on dying during the first year after retirement. Hemmingway et al. (2003) provide a possible explanation of the relatively large effect of early retirement on the probability to die during the first year after retirement. They suggest that retirement may improve health as it takes away the demand from work and stress of work. In our case, the disappearance of demand from work and stress of work may have had a positive effect on health instantly. The immediate positive effect on health may have translated into a negative effect on the probability to die within one year. The difference between the effect of early retirement on dying within four years and the effect of early retirement on dying within five years is even negative, indicating that early retirement has a positive impact on the probability to die during the fifth year. We may expect the probability to die during the years following the fifth year to be positive as well. The reason for this is that since all considered workers will die eventually, irrespective of whether they retire or not, the effect of early retirement on the probability to die in, say, a hundred years, is zero. Because of workers' mortality, we expect the impact of early retirement on mortality to die out when the time horizon for the probability to die is lengthened. This may explain why the effect of early retirement on the probability to die during the fifth year is positive, though the effect of early retirement on the probability to die during the previous years is negative.

\subsection{Robustness checks}

Our statements concerning the probability to die within five years are to be understood conditional on age. Age is an important determinant of both retirement status and the probability to die within five years. This may make our results sensitive to the way age enters our models. We control for second and third order age effects in our instrumental variable model. This baseline estimate is redisplayed as variation a in Table 8. As a robustness check, we estimate the difference-in-difference instrumental variable model once controlling for second order age effects only and once controlling for second, third and fourth order age effects. We perform a similar robustness check for the difference-in-difference-in-difference instrumental variable model. Table 8 shows that the LATE estimates for the alternative models are similar to the LATE estimates for the models we use. This indicates that our instrumental variable results are robust to controlling for age effects of one order lower or one order higher (variations $b$ and $c$ ).

Married men may make retirement decisions in a different way than single men. Married men may, for instance, take into account whether their spouse is retired or whether there are grandchildren present that need attention. As marital status may affect lifestyle, the probability to die within five 
years may also be affected. This may induce the coefficients on, for instance age, in the first and second stage of the instrumental variable models to be different for married men than for single men. We verify whether differences in coefficients between married men and unmarried men affect our LATE estimates. Table 8, variation d, shows that our results do not change much if we only consider workers who are married. Our results do not change much either if we consider married workers only and control for the lagged retirement status and lagged wage income of partners (variation e).

The control group we use consists of civil servants who are either 53 or 54 in 2005. Because we use fixed effects models, the control group effectively consists of civil servants aged 54 only. ${ }^{30}$ We include observations on workers aged 52 to verify whether our results are not driven by particular characteristics of civil servants aged 54 in 2005. Table 8, variation $\mathrm{f}$, shows that our results are robust to including workers aged 52 in our dataset.

III-health workers may have a higher probability to retire early than healthy workers. Since ill-health workers are expected to die sooner than healthy workers, early retirement may have a different effect on mortality for healthy workers than for ill-health workers. We have tried to limit bias due to the potential endogeneity of retirement status to health by dropping observations on workers who have not been hospitalized between 1998 and retirement. We can verify how sensitive our results are to initial health status by estimating the instrumental variable models using observations on workers who have been hospitalized between 1998 and retirement and those who have not been hospitalized between 1998 and retirement. Table 8, variations $g$ and $h$, shows that the LATEs estimated using observations on hospitalized workers only are much larger in magnitude than the LATEs estimated using observations on nonhospitalized workers only. The intuition for this finding is that hospitalized workers have a higher probability to die within five years than nonhospitalized workers, so in terms of health they have more to gain from retirement than nonhospitalized workers. As the number of nonhospitalized civil servant is relatively small, the LATEs for nonhospitalized workers are not significant at the five percent level. The small number of observations on nonhospitalized civil servants also causes the LATEs based on observations of hospitalized and nonhospitalized workers to differ only slightly from the LATEs base on observations of nonhospitalized workers only.

\footnotetext{
${ }^{30}$ Fixed effects models are estimated on observations of individuals who are observed during at least two time units only. Individuals aged 53 in 2005 are observed during only one time unit and are thus not used in the fixed effects analysis.
} 
We estimated the LATEs using instrumental variable models with individual fixed effects. We estimate the instrumental variable models with random effects to verify whether our individual fixed effects LATE estimates are sensitive to imposing the assumption that individual effects are uncorrelated with all covariates. We estimate the random effects instrumental variable models using the difference-in-difference specification as in (1) and (2), and the difference-in-difference-indifference specification in (3) and (4). Table 9 shows that the LATEs for men estimated by the random effects models are significant at the five percent level. The Hausman test results indicate that the random effect coefficient estimates are significantly different from the fixed effects coefficient estimates at the one percent level. The differences between the coefficient estimates estimated by the instrumental variable model with fixed effects and those estimated using the instrumental variable model with random effects indicate that individual effects are correlated with at least some covariates. Individual effects may, for instance, be correlated with lagged wage income. Workers with a higher wage income in the previous period may have time-invariant characteristics that make them more or less likely to retire or more or less likely to die within five years. As individual effects and at least some covariates are correlated, the instrumental variable model with individual fixed effects is preferred over the instrumental variable model with random effects.

\section{Conclusion}

We have studied the impact of early retirement on mortality. We have found that retirement induced by a temporary decrease in the ER eligibility age for civil servants in the Netherlands significantly decreased the probability to die within five years for men by 42.3 percent.

The impact of early retirement on mortality is sizable, indicating that civil servants' probability to survive is sensitive to early retirement. In terms of the Grossman model, the negative impact of early retirement through health on mortality could be explained by a decrease in the opportunity costs to invest in health after retirement. Such a price effect may induce retirees to invest more in health, reducing their probability to die within five years. An alternative explanation would be that working brings about stress. After retirement, workers' body and mind are possibly discharged, reducing the probability to die within five years. As men were working more hours than women, work may have been more stressful and demanding for men than for women, discharging men from a heavier weight at retirement than women. In turn, retirement may have had a negative and significant impact on the probability to die within five years for men. Results using primary causes of death at 
least point to the possibility that stress-related conditions are important in explaining the number of lives lost due to work.

Our main results are that early retirement induced by the decrease in the ER eligibility age had a negative impact on mortality. This result has at least two policy implications. First, in times of crisis, companies may consider reducing their workforce by offering early retirement to workers. If employers will let their older workers retire early, this may impose longevity risk to pension funds. Pension funds would need to anticipate on this to prevent sustainability problems. Second, the ER eligibility age is increasing in many countries. If an increase in the ER eligibility age were to have the opposite effect on mortality as a decrease in ER eligibility age, an increase in the ER eligibility age would have a positive impact on mortality. Increased mortality would have a negative impact on the longevity risk borne by pension funds. This may allow pension funds to make their pension arrangements more generous.

Using our findings, we make a back-of-the-envelope calculation on the amount of pension benefits that are paid extra due to retired civil servants living longer than civil servants who are not induced to retire by the introduction of the early retirement arrangement. ${ }^{31}$ We assume that the effect of early retirement on the probability to die within one to five years is given by the LATE estimates. Because we have data on mortality up to five years ahead only, we impute the effect of early retirement on the probability to die within six years or more. ${ }^{32}$ Table 10 shows the hypothesized LATEs. From these hypothesized LATES we can calculate that the introduction of the early retirement arrangement induced early retirees to live 56 days, or almost two months, longer than their equivalents who did not retire. During these 56 days, the early retirees receive pension benefits. When retirement benefits minus pension accrual costs equal 20,000 Euros per year, the cost of the retirement benefits paid to the 2,348 workers who were induced to retire during the 56 days with which their life was extended by early retirement amounts about 7,000,000 Euros. ${ }^{33}$ This is a substantial amount, especially given the small number of workers affected by the introduction of the early retirement arrangement.

\footnotetext{
${ }^{31}$ We do thus not take into account the effect of early retirement on e.g. health costs. We do also not consider the possibly positive effect of early retirement on employment opportunities of young civil servants.

${ }^{32}$ The effect of retirement on mortality within five years is weaker than the effect of retirement on mortality within four years. We assume that the LATE weakens further for mortality more than five years ahead and that there is ultimately no effect of retirement on mortality eight years ahead.

${ }^{33}$ When workers live two months longer, they receive next to their pension benefits also two months of oldage pension benefits.
} 


\section{References}

Appel, L.J., M.W. Brands, S.R. Daniels, P.J. Elmer, N. Karanja and F.M. Sacks (2006), “Dietary approaches to prevent and treat hypertension: a scientific statement from the American Heart Association", Hypertension 47: 296-308

Bazolli, G.J. (1985), "The early retirement decision: new empirical evidence on the influence of health", Journal of Human Resources 20: 214-234

Begg, S., C. Mathers and T. Truelsen (2006), "The global burden of cerebrovascular disease", World Health Organization (WHO) report

Behncke, S. (2012), “Does retirement trigger ill health?”, Health Economics 21: 282-300

Blake, H. and C. Garrouste (2012a), "Collateral effects of a pension reform in France", Paris School of Economics Working Paper No. 2012-25

Blake, H. and C. Garrouste (2012b), "Killing me softly: work and mortality among French seniors", Manuscript

Boaz, R.F. and C.F. Muller (1989), "Does having more time after retirement change the demand for physician services?", Medical Care 27: 1-15

Bovenberg, A.L. and L. Meijdam (2001), "The Dutch pension system", in: A.H. Börsch-Supan and M. Miegel (eds.), "Pension reform in six countries. What can we learn from each other?", Berlin: Springer

Brown, R.L. and J. McDaid (2003), "Factors affecting retirement mortality", North American Actuarial Journal 7: 24-43

Browning, M., A.M. Dan $\varnothing$ and E. Heinesen (2006), "Job displacement and health outcomes: a representative panel study", Health Economics 15: 1061-1075

Charles, K.K. (2004), "Is retirement depressing? Labor force inactivity and psychological well-being in later life", Research in Labor Economics 23: 269-299

Coe, N.B. and M. Lindeboom (2008), "Does retirement kill you? Evidence from early retirement windows", Institute for the Study of Labor (IZA) Discussion Paper 3817

Coe, N.B. and G. Zamaro (2011), "Retirement effects on health in Europe", Journal of Health Economics 30: 77-86

Dave, D., I. Rashad, and J. Spasojevic (2008), "The effects of retirement on physical and mental health outcomes", Southern Economic Journal 75: 497-523 
Dwyer, D.S. and O.S. Mitchell (1999), "Health problems as determinants of retirement: are self-rated measures endogenous?", Journal of Health Economics 18: 173-193

Grossman, M. (1972), "On the concept of health capital and the demand for health", Journal of Political Economy 80: 223-255

Hemingway, H., M. Marmot, P. Martikainen, G. Mein and S. Stansfeld (2003), "Is retirement good or bad for mental and physical health functioning? Whitehall II longitudinal study of civil servants", Journal of Epidemiology and Community Health 57: 46-49

Kaplan, M.S. and A. Nunes (2003), "The psychosocial determinants of hypertension", Nutrition Metabolism and Cardiovascular diseases 13: 52-59

Kerkhofs, M. and M. Lindeboom (2009), "Health and work of the elderly: subjective health measures, reporting errors and endogeneity in the relationship between health and work", Journal of Applied Econometrics 24: 1024-1046

Kuhn, A., J.P. Wuellrich and J. Zweimueller (2010), "Fatal attraction? Access to early retirement and mortality", Institute for the Study of Labor (IZA) Discussion Paper 5160

Midanik L.T., L.J. Ransom, K. Soghikian and I.S. Tekawa (1995), "The effect of retirement on mental health and health behaviors: the Kaiser Permanente Retirement Study", Journals of Gerontology Series B Psychological Sciences and Social Sciences 50: S59-S61

Neuman, K. (2008), "Quit your job and get healthier? The effect of retirement on health", Journal of Labor Research 29: 177-201

Roos, N.P. and E. Shapiro (1982), "Retired and employed elderly persons: their utilization of health care services", The Gerontologist 22: 187-193

Salm, M. (2009), “Does job loss cause ill health?”, Health Economics 18: 1075-1089

Sullivan, D. and T. von Wachter (2009), "Job displacement and mortality: an analysis using administrative data", The Quarterly Journal of Economics 124: 1265-1306

World Health Organization (2010), International Statistical Classification of Diseases and Related Health Problems $10^{\text {th }}$ Revision 


\section{Appendix}

\section{The Dutch pension system}

The Dutch pension system rests on three pillars (Bovenberg and Meijdam, 2001). The first pillar is the public old-age pension. The public old-age pension is financed on a pay-as-you-go basis. Contributions stem from workers and employers. All residents registered in the Netherland accrue public old-age pension rights. Public old-age pension benefits are flat. For couples they equal the minimum wage. Singles receive 70 percent of the minimum wage. For every year between the ages 15 and 65 that an individual did not reside in the Netherlands, public old-age benefits are cut by two percentage points. The second pillar consists of occupational pensions. Occupational pensions are funded pensions and are generally managed on the sector level. ${ }^{34}$ About 90 percent of the workers participate in an occupational pension plan. Occupational pension schemes receive contributions from workers and employers. Workers who participate in a pension plan pay contributions over the difference between their wage and a nominal threshold called the "franchise". As every firm or sector has its own pension plan and pension conditions, there is a large heterogeneity among occupational pensions. At the time at which the early retirement arrangement under review was introduced, there was also a large heterogeneity in early retirement arrangements. The third pillar consists of private provisions. Private provisions include amongst others annuity insurance.

\section{Regular early retirement arrangements for civil servants}

As of April $1^{\text {st }}, 1997$, early retirement benefits for civil servants consisted of two parts. The first part was in general 70 percent of the "franchise" for civil servants who had worked full-time during their working life. ${ }^{35}$ The first part intended to compensate early retirees for the lack of old-age pension benefits for the period between early retirement and normal retirement. Civil servants were eligible for the first part if they satisfied two conditions. First, they had to have been employed as a civil servant continuously during the ten years prior to early retirement. Second, they had to have contributed continuously to the public pension fund during the ten years preceding early retirement. The first part of early retirement benefits was in general higher when a civil servant retired at a later age. The first part was financed on a pay-as-you-go-basis. Workers and employers contributed to the early retirement benefit scheme. Part two of early retirement benefits was funded. Workers and employers contributed to the accrual of benefits in the second part. When a civil servant would have accrued benefits for 40 years, the sum of the first and second part would have been 70 percent of

\footnotetext{
${ }^{34}$ Various large employers have their own pension fund.

${ }^{35}$ This replacement rate is based on retirement at the ER eligibility age. The ER eligibility age depends on the birth date of an individual.
} 
the final wage. ${ }^{36} 37$ The replacement rate was reduced by 1.75 percentage points for every year a civil servant would have accrued benefits less than 40 years. Civil servants were allowed to do paid work after early retirement. However, total income of a retired civil servant was not allowed to exceed 100 percent of the final gross wage. ${ }^{38}$ If the total income of a retired civil servant exceeded 100 percent of the final gross wage, early retirement benefits were cut as much as needed to bring the total income earned on 100 percent of the final gross wage.

\section{Other policy changes}

On January $1^{\text {st }}, 2004$, the public sector pension fund switched from a final wage pension system to a average wage pension system. ${ }^{39}$ However, due to a transition arrangement, civil servants born before January $1^{\text {st }}, 1954$ were hardly affected by the switch.

On January $1^{\text {st }}, 2006$, the so-called fiscal facilitation of early retirement benefits for individuals born January $1^{\text {st }}, 1950$ or later was terminated. ${ }^{40}$ This implied that most early retirement arrangements for the affected individuals disappeared. Early retirement among civil servants usually occurred at age 61 or 62 . The termination of the fiscal facilitation of early retirement benefits could have been anticipated as of 2003 and may have induced anticipation effects of civil servants aged 53-55 in 2005.

\footnotetext{
${ }^{36}$ This replacement rate is based on retirement at the ER eligibility age. The ER eligibility age depends on the birth date of an individual.

${ }^{37}$ On January $1^{\text {st }}, 2004$, the public sector pension fund switched from a final wage pension system to an average wage pension system.

${ }^{38}$ Income does not only include wage income here, but also some other specified sources of income.

${ }^{39}$ The pension fund for the health care sector also switched from a final wage system to a mean wage system on January $1^{\text {st }}, 2004$. Many other pension funds also switched in the years before or after January $1^{\text {st }}, 2004$.

${ }^{40}$ The fiscal facilitation of the early retirement contributions implied that the early retirement benefits were taxed, and that the early retirement contributions paid by workers and employers were exempted from taxation. As effectively less tax was paid, the fiscal facilitation made early retirement very attractive for eligible workers and employers.
} 


\section{Figures and Tables}

Figure 1: Probability to die within five years, civil servants, by birth cohort (percentages)*

Figure 1a: men

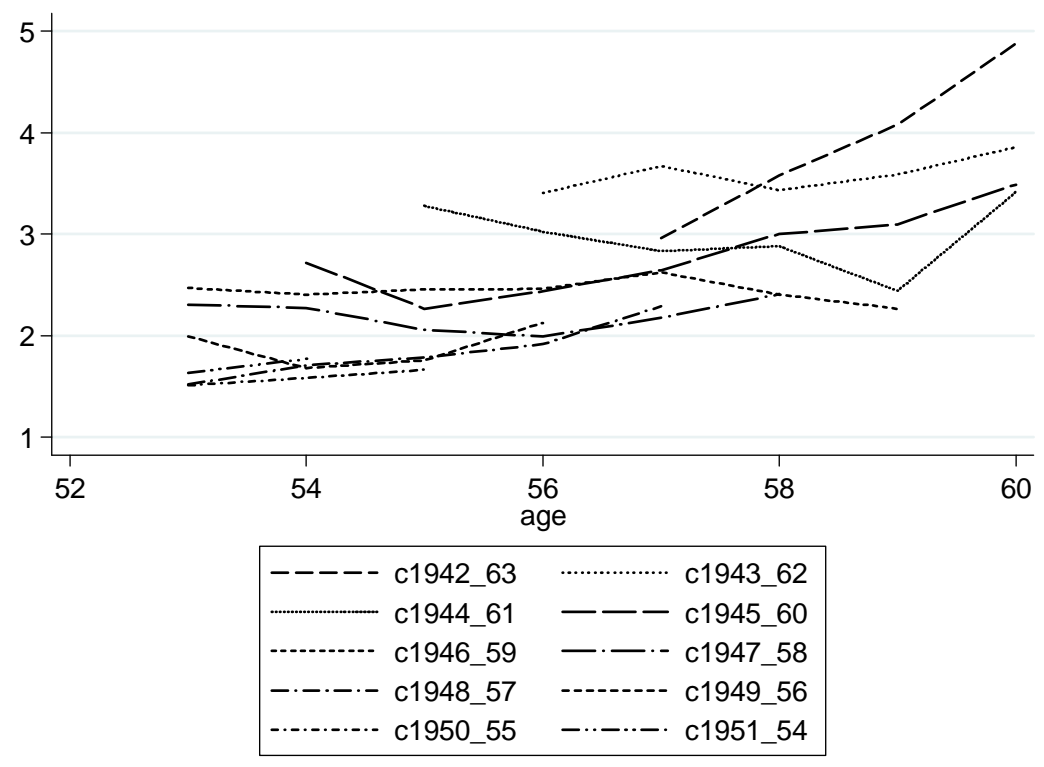

Figure 1b: women

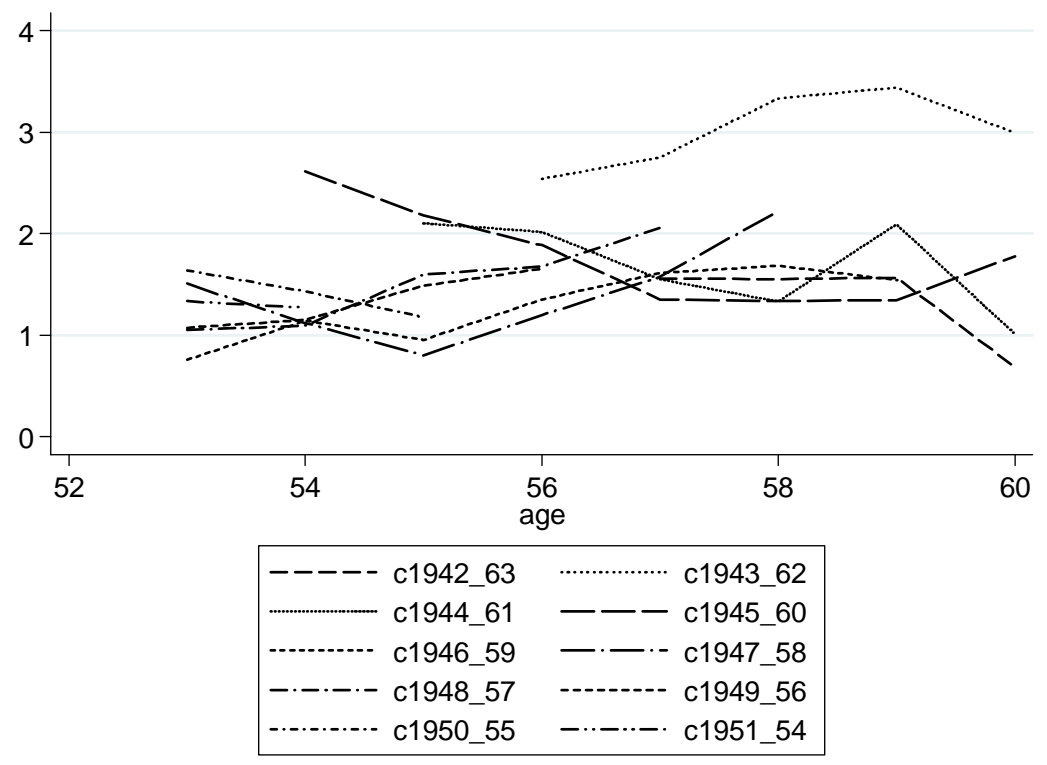

* Age on December $31^{\text {st }}, 2005$ is indicated behind each birth cohort. This figure is based on data for 1999-2005. 
Figure 2: Probability to die within five years, full Dutch population, by birth cohort (percentages)* Figure 2a: men

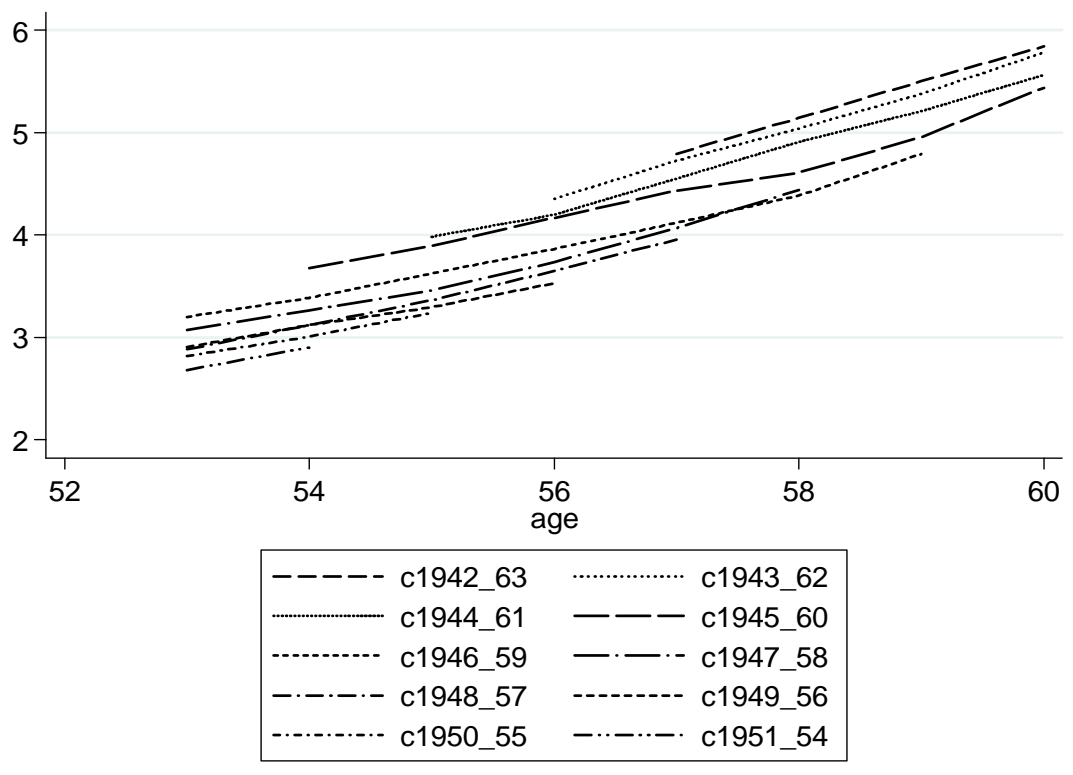

Figure $2 \mathrm{~b}$ : women

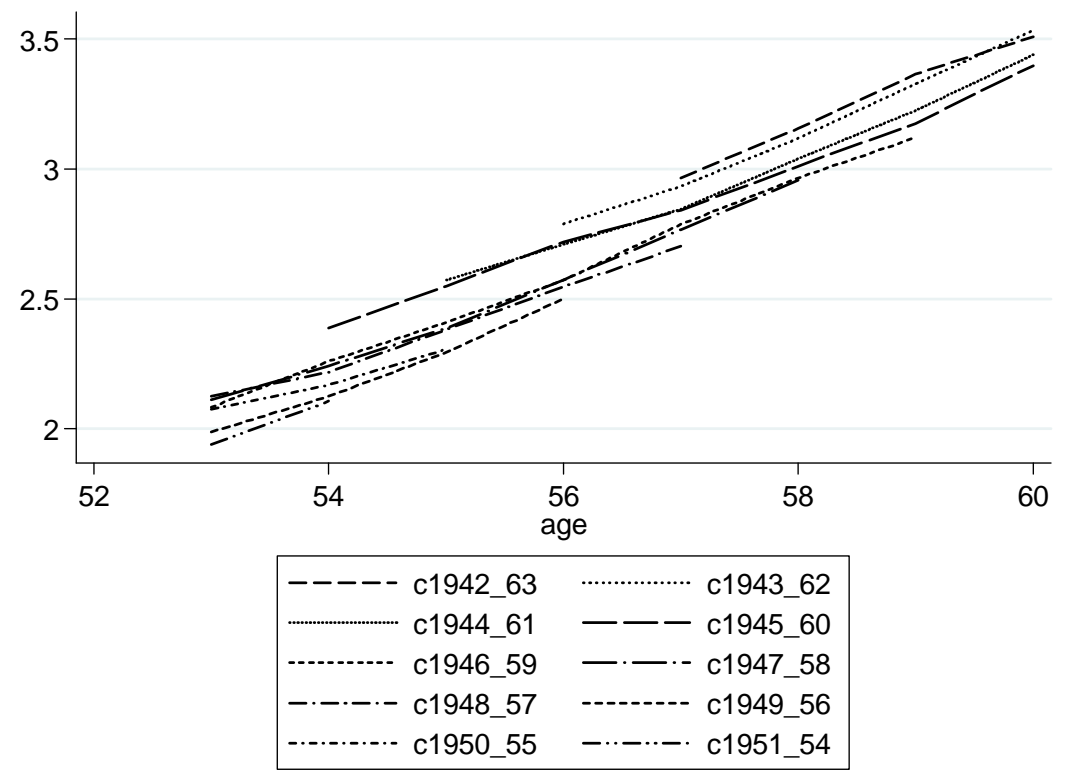

* Age on December $31^{\text {st }}, 2005$ is indicated behind each birth cohort. This figure is based on data for 1999-2005. 
Figure 3: Retirement rates for civil servants, by birth cohort (percentages)* Figure 3a: men

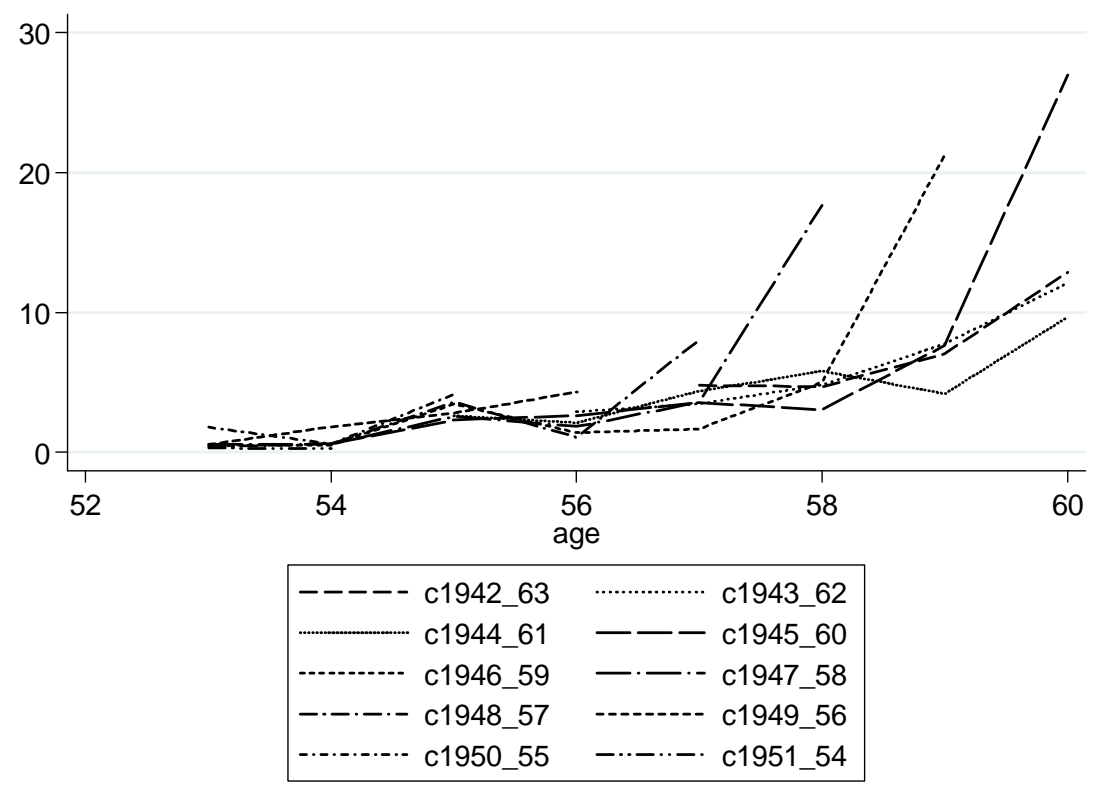

Figure 3b: women

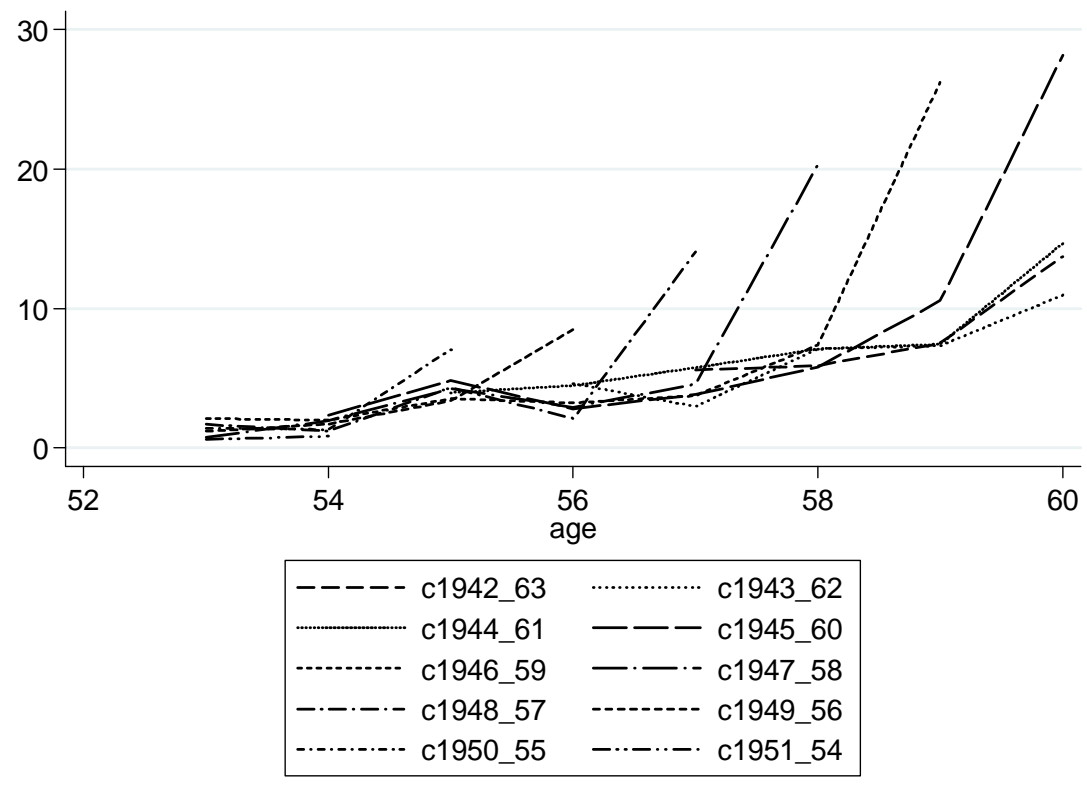

*Age on December $31^{\text {st }}, 2005$ is indicated behind each birth cohort. This figure is based on data for 1999-2005. 
Figure 4: Retirement rates for employees outside the public sector, by birth cohort (percentages)* Figure 4a: men

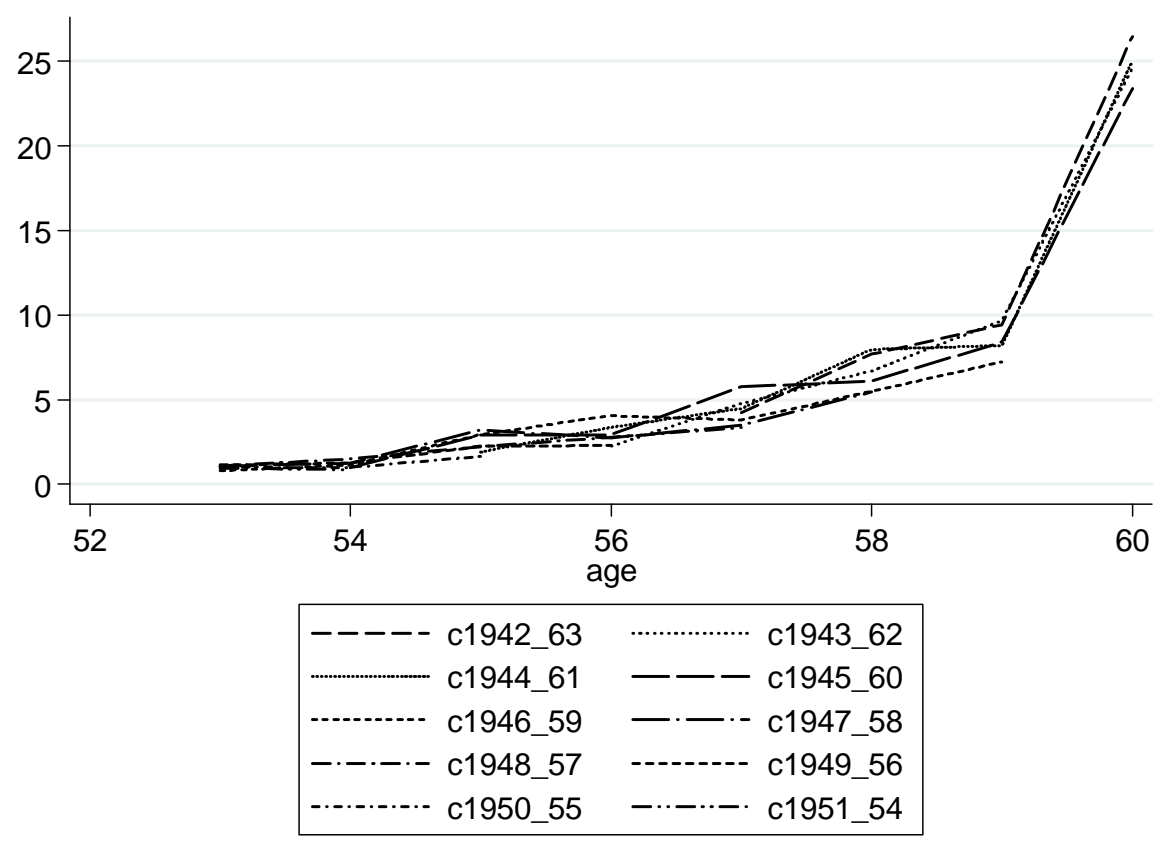

Figure 4b: women

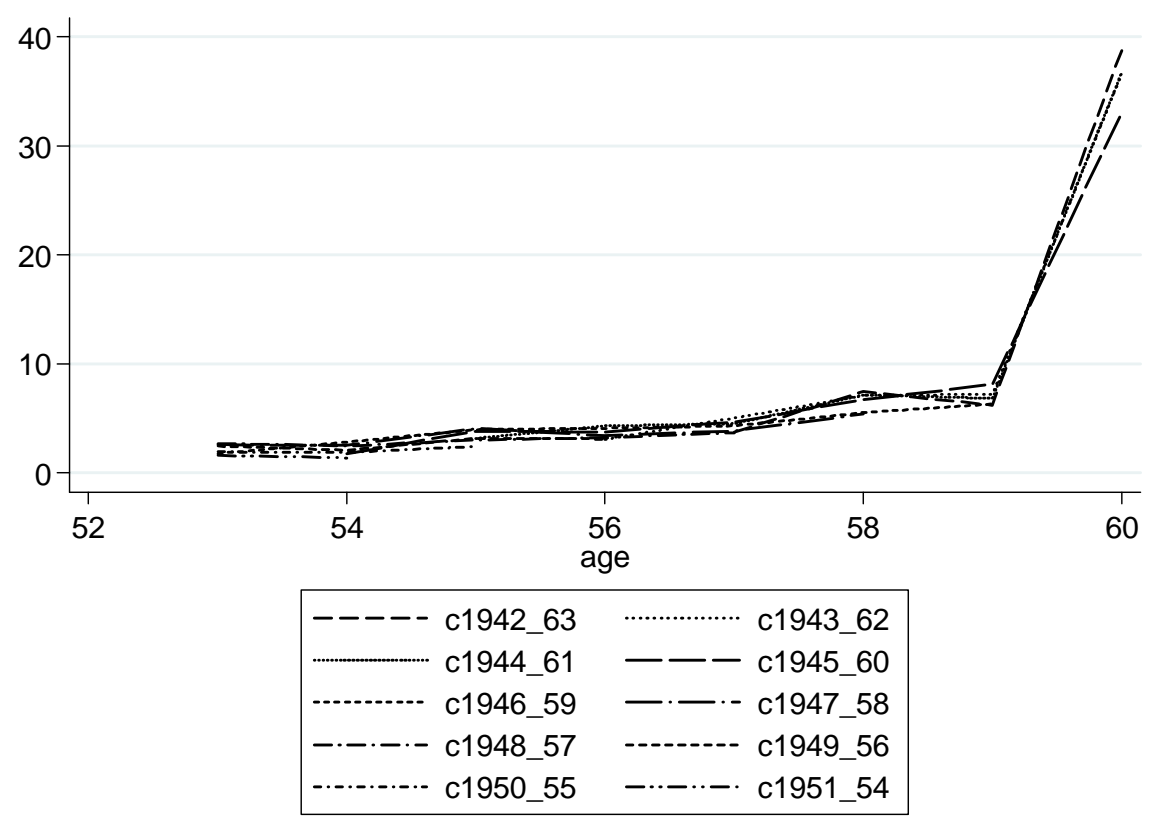

* Age on December $31^{\text {st }}, 2005$ is indicated behind each birth cohort. This figure is based on data for 1999-2005. 
Figure 5: Probability to die within five years for employees outside the public sector, by birth cohort (percentages)*

Figure 5a: men

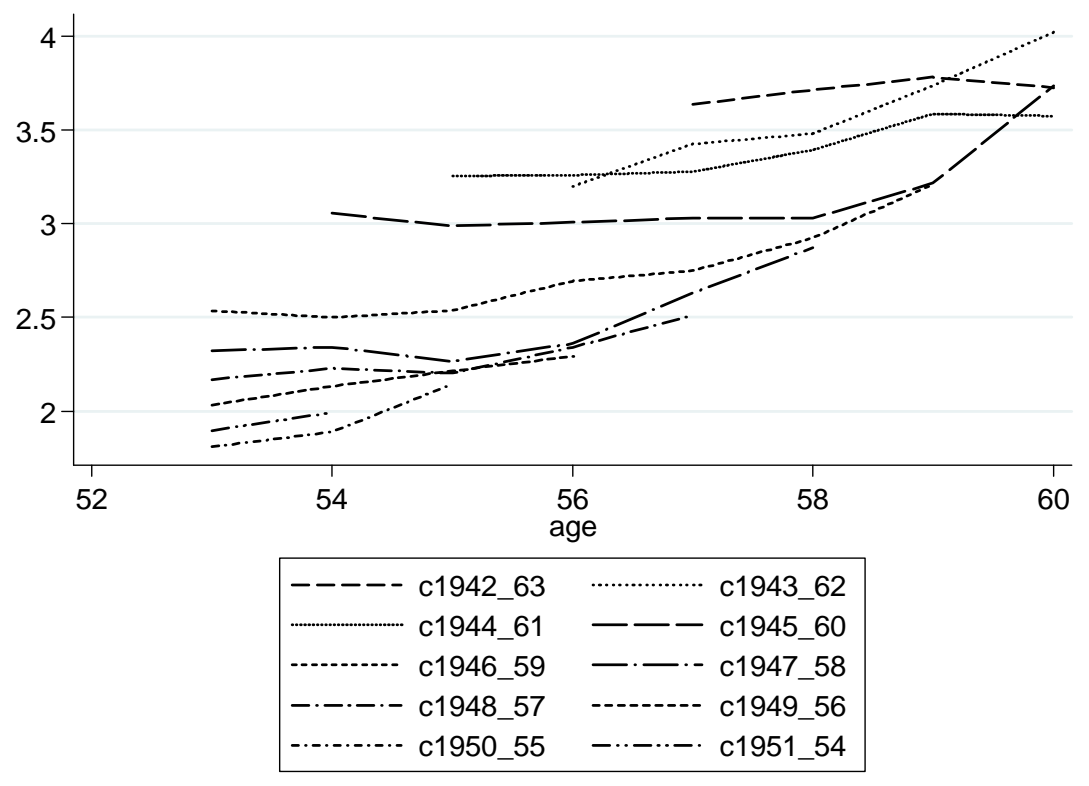

Figure 5b: women

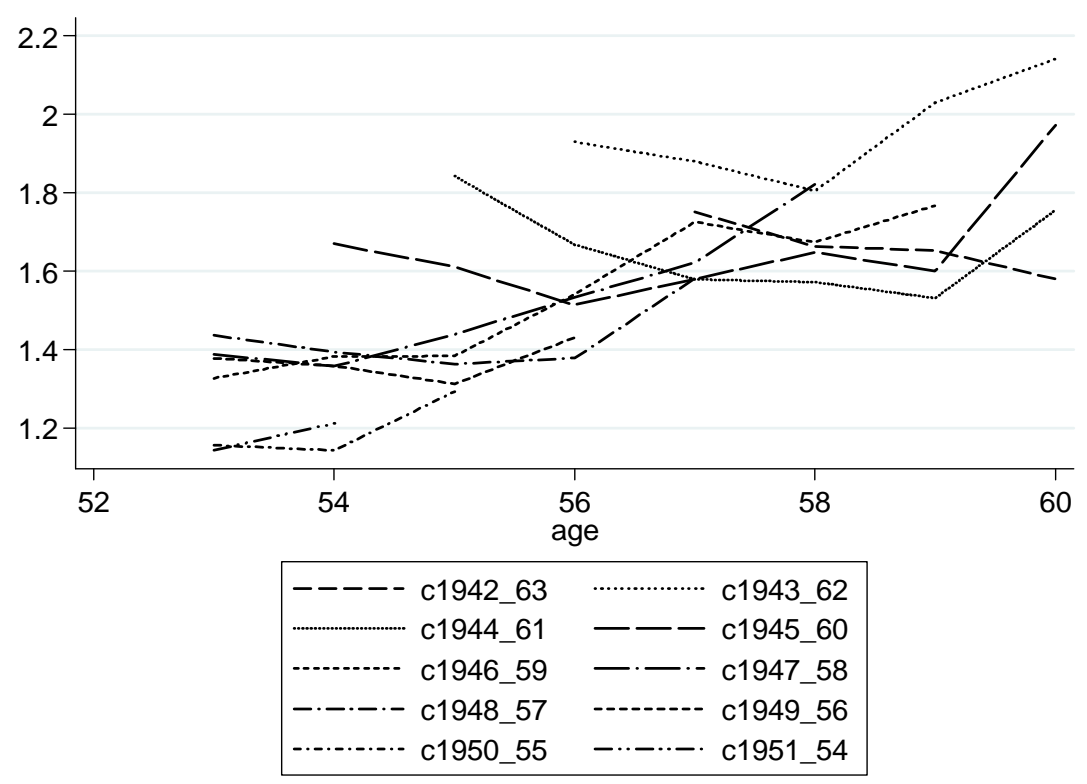

* Age on December $31^{\text {st }}, 2005$ is indicated behind each birth cohort. This figure is based on data for 1999-2005. 
Table 1: Literature overview

\begin{tabular}{|c|c|c|c|c|c|c|c|}
\hline Paper & Data & Population & $\begin{array}{l}\text { Source of exogenous } \\
\text { variation in retirement } \\
\text { status }\end{array}$ & $\begin{array}{l}\text { Country of } \\
\text { study }\end{array}$ & Methodology & $\begin{array}{l}\text { Outcome } \\
\text { variable }\end{array}$ & Main results \\
\hline $\begin{array}{l}\text { Charles } \\
\text { (2004) }\end{array}$ & $\begin{array}{l}\text { HRS, AHEAD, } \\
\text { NLS-MM }\end{array}$ & Men & Institutional change & US & IV & Health & Positive effect on well-being \\
\hline $\begin{array}{l}\text { Neuman } \\
(2008)\end{array}$ & HRS & $\begin{array}{l}\text { Men and } \\
\text { women }\end{array}$ & Institutional change & US & IV & Health & $\begin{array}{l}\text { Positive effect on subjective } \\
\text { health for men and women }\end{array}$ \\
\hline $\begin{array}{l}\text { Coe and } \\
\text { Lindeboom } \\
\text { (2008) }\end{array}$ & HRS & Men & Retirement window & US & IV & $\begin{array}{l}\text { Mortality } \\
\text { and health }\end{array}$ & $\begin{array}{l}\text { Positive effect on health for } \\
\text { highly educated workers }\end{array}$ \\
\hline $\begin{array}{l}\text { Blake and } \\
\text { Garrouste } \\
\text { (2012b) }\end{array}$ & $\begin{array}{l}\text { Baromètre } \\
\text { Santé }\end{array}$ & $\begin{array}{l}\text { Male private } \\
\text { sector workers }\end{array}$ & Institutional change & France & IV & Mortality & $\begin{array}{l}\text { Negative effect on mortality } \\
\text { within four years }\end{array}$ \\
\hline $\begin{array}{l}\text { Kuhn et al. } \\
(2010)\end{array}$ & $\begin{array}{l}\text { Administra- } \\
\text { tive data }\end{array}$ & $\begin{array}{l}\text { Male and } \\
\text { female blue- } \\
\text { collar workers }\end{array}$ & Regional change in UI & Austria & IV & Mortality & $\begin{array}{l}\text { Positive effect for men, no } \\
\text { effect for women }\end{array}$ \\
\hline $\begin{array}{l}\text { Behncke } \\
\text { (2012) }\end{array}$ & ELSA & $\begin{array}{l}\text { Men and } \\
\text { women }\end{array}$ & $\begin{array}{l}\text { Eligibility age for public } \\
\text { old-age benefits }\end{array}$ & UK & $\begin{array}{l}\text { IV, propensity } \\
\text { score matching }\end{array}$ & Health & $\begin{array}{l}\text { Negative effect on physical } \\
\text { health for men and women }\end{array}$ \\
\hline $\begin{array}{l}\text { Hemingway } \\
\text { et al. (2003) }\end{array}$ & $\begin{array}{l}\text { Whitehall II } \\
\text { study }\end{array}$ & $\begin{array}{l}\text { Male and } \\
\text { female civil } \\
\text { servants }\end{array}$ & Institutional change & UK & $\begin{array}{l}\text { Before-after dif- } \\
\text { in-dif }\end{array}$ & Health & $\begin{array}{l}\text { Positive effect on mental } \\
\text { health for male and female } \\
\text { high wage workers }\end{array}$ \\
\hline $\begin{array}{l}\text { Dave et al. } \\
\text { (2008) }\end{array}$ & HRS, AHEAD & $\begin{array}{l}\text { Men and } \\
\text { women }\end{array}$ & $\begin{array}{l}\text { None - consider only } \\
\text { workers who were } \\
\text { healthy before retirement }\end{array}$ & US & Linear FE & Health & $\begin{array}{l}\text { Negative effect on general } \\
\text { health for men and women }\end{array}$ \\
\hline
\end{tabular}


Table 2: Descriptive statistics

Men

Women

\begin{tabular}{|c|c|c|c|c|c|c|c|c|}
\hline \multirow[b]{3}{*}{ Variable } & \multicolumn{4}{|c|}{ Men } & \multicolumn{4}{|c|}{ Women } \\
\hline & \multicolumn{2}{|c|}{ Civil servants, 1999-2005 } & \multicolumn{2}{|c|}{ Other workers, 1999-2005 } & \multicolumn{2}{|c|}{ Civil servants, 1999-2005 } & \multicolumn{2}{|c|}{ Other workers, 1999-2005 } \\
\hline & Mean & Std. dev. & Mean & Std. dev. & Mean & Std. dev. & Mean & Std. dev. \\
\hline Age & 55.90 & 2.21 & 55.98 & 2.18 & 55.81 & 2.19 & 55.93 & 2.18 \\
\hline Married & 0.85 & 0.36 & 0.84 & 0.37 & 0.63 & 0.48 & 0.71 & 0.45 \\
\hline Wage income $[\mathrm{t}-1]$ & 37.40 & 13.36 & 37.40 & 22.38 & 24.65 & 13.04 & 18.41 & 11.56 \\
\hline \multicolumn{9}{|l|}{ (in 1000s of Euros) } \\
\hline \multirow[t]{3}{*}{ N } & 155,021 & & $1,137,756$ & & 34,491 & & 507,505 & \\
\hline & \multicolumn{4}{|c|}{ Male civil servants } & \multicolumn{4}{|c|}{ Female civil servants } \\
\hline & \multicolumn{2}{|c|}{ Control group, y. 2005} & \multicolumn{2}{|c|}{ Treatment group, y. 2005} & \multicolumn{2}{|c|}{ Control group, y. 2005} & \multicolumn{2}{|c|}{ Treatment group, y. 2005} \\
\hline Variable & Mean & Std. dev. & Mean & Std. dev. & Mean & Std. dev. & Mean & Std. dev. \\
\hline Age & 53.47 & 0.50 & 57.16 & 1.62 & 53.47 & 0.50 & 57.08 & 1.61 \\
\hline Married & 0.81 & 0.39 & 0.84 & 0.37 & 0.66 & 0.47 & 0.63 & 0.48 \\
\hline Wage income $[t-1]$ & 37.40 & 12.77 & 38.20 & 14.09 & 25.69 & 12.63 & 25.09 & 13.67 \\
\hline (in 1000s of Euros) & & & & & & & & \\
\hline \multirow[t]{3}{*}{$\mathrm{N}$} & 9,062 & & 19,644 & & 2,522 & & 4,650 & \\
\hline & \multicolumn{4}{|c|}{ Male other workers } & \multicolumn{4}{|c|}{ Female other workers } \\
\hline & \multicolumn{2}{|c|}{ Ages 53-54, y. 2005} & \multicolumn{2}{|c|}{ Ages 55-60, y. 2005} & \multicolumn{2}{|c|}{ Ages 53-54, y. 2005} & \multicolumn{2}{|c|}{ Ages 55-60, y. 2005} \\
\hline Variable & Mean & Std. dev. & Mean & Std. dev. & Mean & Std. dev. & Mean & Std. dev. \\
\hline Age & 53.48 & 0.50 & 57.24 & 1.63 & 53.48 & 0.50 & 57.19 & 1.64 \\
\hline Married & 0.81 & 0.39 & 0.83 & 0.37 & 0.73 & 0.45 & 0.71 & 0.45 \\
\hline Wage income [t-1] & 37.36 & 21.65 & 37.84 & 23.11 & 19.90 & 11.56 & 18.90 & 11.78 \\
\hline (in 1000s of Euros) & & & & & & & & \\
\hline $\mathrm{N}$ & 60,997 & & 145,589 & & 31,671 & & 69,506 & \\
\hline
\end{tabular}


Table 3: Uninstrumented fixed effects estimates for the probability to die within five years for civil servants*

\begin{tabular}{lllll} 
& Dif-in-dif & \multicolumn{3}{l}{ Dif-in-dif-in-dif } \\
\hline $\mathrm{N}$ & Men & Women & Men & Women \\
\hline $\begin{array}{l}\text { Coefficient estimate } \\
\text { retirement }(\widehat{\omega})\end{array}$ & 0.006 & -0.001 & 0.004 & 0.001 \\
$\begin{array}{l}\text { P-value } \\
\text { Fraction of total variation }\end{array}$ & 0.000 & 0.465 & 0.000 & 0.005 \\
$\begin{array}{l}\text { explained by individual fixed } \\
\text { effects }\end{array}$ & 0.802 & 0.796 & 0.802 & 0.803 \\
& & & & \\
\end{tabular}

Table 4: Fixed effects instrumental variable estimates for the probability to die within five years*

\begin{tabular}{|c|c|c|c|c|}
\hline & \multicolumn{2}{|l|}{ Dif-in-dif } & \multicolumn{2}{|c|}{ Dif-in-dif-in-dif } \\
\hline & Men & Women & Men & Women \\
\hline $\mathrm{N}$ & 147,283 & 32,495 & $1,233,529$ & 514,117 \\
\hline $\begin{array}{l}\text { Coefficient estimate } \\
\text { retirement }(\widehat{\omega})\end{array}$ & -0.025 & -0.003 & -0.025 & -0.002 \\
\hline P-value & 0.058 & 0.889 & 0.057 & 0.889 \\
\hline $\begin{array}{l}\text { F statistic on instruments in } \\
\text { first stage }\end{array}$ & 196.77 & 32.83 & 173.98 & 34.94 \\
\hline P-value & 0.000 & 0.000 & 0.000 & 0.000 \\
\hline P-value J statistic & 0.231 & 0.043 & 0.231 & 0.045 \\
\hline $\begin{array}{l}\text { Fraction of total variation } \\
\text { explained by individual fixed } \\
\text { effects in first stage }\end{array}$ & 0.301 & 0.349 & 0.470 & 0.662 \\
\hline $\begin{array}{l}\text { Fraction of total variation } \\
\text { explained by individual fixed } \\
\text { effects in second stage }\end{array}$ & 0.803 & 0.796 & 0.803 & 0.804 \\
\hline
\end{tabular}

* The model estimated here controls for lagged wage income, marital status, year fixed effects, nonlinear age effects and individual fixed effects. The p-values on the coefficient are based on heteroskedasticity robust standard errors. 
Table 5: Fixed effects instrumental variable estimates for the probability to die within five years for male civil servants (difference-in-difference)*

\begin{tabular}{|c|c|c|c|c|c|}
\hline Cause of death & LATE & P-value & $\begin{array}{l}\text { P-value } \\
\text { J statistic }\end{array}$ & $\begin{array}{l}\text { LATE } \\
\text { (in \# of } \\
\text { deaths) }\end{array}$ & $\begin{array}{l}\text { \# of deaths } \\
\text { civ. serv., } \\
1999-2010\end{array}$ \\
\hline Neoplasms & -0.003 & 0.761 & 0.002 & -7.2 & 838 \\
\hline Malignant neoplasms of lip, oral cavity and pharynx & -0.001 & 0.352 & 0.188 & -2.6 & 20 \\
\hline Malignant neoplasms of digestive organs & 0.002 & 0.709 & 0.095 & 5.4 & 266 \\
\hline Malignant neoplasms of respiratory and intrathoracic organs & -0.002 & 0.654 & 0.379 & -5.8 & 228 \\
\hline Melanoma and other malignant neoplasms of skin & 0.001 & 0.609 & 0.231 & 2.0 & 34 \\
\hline Malignant neoplasms of mesothelial and soft tissue & -0.000 & 0.780 & 0.367 & -1.0 & 18 \\
\hline Malignant neoplasms of male genital organs & -0.001 & 0.492 & 0.666 & -3.3 & 49 \\
\hline Malignant neoplasms of urinary tract & -0.002 & 0.550 & 0.079 & -3.7 & 70 \\
\hline Malignant neoplasms of eye, brain and other parts of central nervous system & -0.003 & 0.191 & 0.164 & -6.1 & 43 \\
\hline Malignant neoplasms of ill-defined, secondary and unspecified sites & 0.001 & 0.600 & 0.082 & 2.7 & 34 \\
\hline $\begin{array}{l}\text { Malignant neoplasms, stated or presumed to be primary, of lymphoid, haematopoietic } \\
\text { and related tissue }\end{array}$ & 0.002 & 0.527 & 0.290 & 4.4 & 61 \\
\hline Neoplasms of uncertain or unknown behavior & 0.000 & 0.385 & 0.708 & 0.7 & 15 \\
\hline Endocrine, nutritional and metabolic diseases & -0.001 & 0.614 & 0.479 & -1.5 & 22 \\
\hline Mental and behavioural disorders & -0.001 & 0.189 & 0.249 & -1.9 & 15 \\
\hline Diseases of the nervous system & -0.001 & 0.580 & 0.830 & -1.5 & 26 \\
\hline Diseases of the circulatory system & -0.007 & 0.311 & 0.996 & -15.7 & 452 \\
\hline Hypertensive diseases & -0.002 & 0.257 & 0.083 & -3.6 & 22 \\
\hline Ischaemic heart diseases & -0.006 & 0.170 & 0.888 & -14.1 & 215 \\
\hline Other forms of heart disease & 0.007 & 0.085 & 0.025 & 17.1 & 138 \\
\hline Cerebrovascular diseases & -0.005 & 0.004 & 0.555 & -11.9 & 51 \\
\hline Diseases of arteries, arterioles and capillaries & -0.001 & 0.288 & 0.623 & -3.2 & 28 \\
\hline Diseases of the respiratory system & 0.002 & 0.474 & 0.150 & 3.5 & 33 \\
\hline Diseases of the digestive system & -0.007 & 0.004 & 0.097 & -17.0 & 49 \\
\hline Symptoms, signs and abnormal clinical and laboratory findings, not elsewhere classified & -0.004 & 0.220 & 0.982 & -8.9 & 88 \\
\hline External causes of morbidity and mortality & -0.004 & 0.089 & 0.849 & -9.1 & 69 \\
\hline Other diseases & -0.000 & 0.970 & 0.452 & -0.2 & 28 \\
\hline Total & -0.025 & & & -59.4 & 1,621 \\
\hline
\end{tabular}


Table 6: Fixed effects instrumental variable estimates for the probability to die within five years for male civil servants

(difference-in-difference-in-difference)*

\begin{tabular}{|c|c|c|c|c|c|}
\hline Cause of death & LATE & P-value & $\begin{array}{l}\text { P-value } \\
\text { J statistic }\end{array}$ & $\begin{array}{l}\text { LATE } \\
\text { (in \# of } \\
\text { deaths) }\end{array}$ & $\begin{array}{l}\text { \# of deaths } \\
\text { civ. serv., } \\
\text { 1999-2010 }\end{array}$ \\
\hline Neoplasms & -0.003 & 0.751 & 0.002 & -7.5 & 838 \\
\hline Malignant neoplasms of lip, oral cavity and pharynx & -0.001 & 0.325 & 0.185 & -2.4 & 20 \\
\hline Malignant neoplasms of respiratory and intrathoracic organs & -0.003 & 0.646 & 0.379 & -5.9 & 230 \\
\hline Melanoma and other malignant neoplasms of skin & 0.001 & 0.607 & 0.228 & 2.0 & 34 \\
\hline Malignant neoplasms of mesothelial and soft tissue & -0.000 & 0.778 & 0.367 & -1.0 & 18 \\
\hline Malignant neoplasms of eye, brain and other parts of central nervous system & -0.003 & 0.195 & 0.163 & -6.1 & 42 \\
\hline Malignant neoplasms of ill-defined, secondary and unspecified sites & 0.001 & 0.595 & 0.079 & 2.8 & 34 \\
\hline $\begin{array}{l}\text { Malignant neoplasms, stated or presumed to be primary, of lymphoid, haematopoietic } \\
\text { and related tissue }\end{array}$ & 0.002 & 0.528 & 0.287 & 4.4 & 61 \\
\hline Neoplasms of uncertain or unknown behavior & 0.000 & 0.379 & 0.670 & 0.7 & 15 \\
\hline Endocrine, nutritional and metabolic diseases & -0.001 & 0.616 & 0.482 & -1.4 & 22 \\
\hline Ischaemic heart diseases & -0.006 & 0.166 & 0.888 & -14.2 & 215 \\
\hline Other forms of heart disease & 0.007 & 0.087 & 0.024 & 16.9 & 138 \\
\hline Cerebrovascular diseases & -0.005 & 0.004 & 0.550 & -11.8 & 51 \\
\hline Diseases of arteries, arterioles and capillaries & -0.001 & 0.285 & 0.606 & -3.2 & 28 \\
\hline Diseases of the respiratory system & 0.002 & 0.472 & 0.148 & 3.5 & 34 \\
\hline Diseases of the digestive system & -0.007 & 0.005 & 0.104 & -16.7 & 49 \\
\hline Symptoms, signs and abnormal clinical and laboratory findings, not elsewhere classified & -0.004 & 0.222 & 0.983 & -8.8 & 88 \\
\hline External causes of morbidity and mortality & -0.004 & 0.090 & 0.849 & -9.1 & 68 \\
\hline Other diseases & -0.000 & 0.906 & 0.527 & -0.2 & 27 \\
\hline Total & -0.025 & & & -59.2 & 1,622 \\
\hline
\end{tabular}


Table 7: Fixed effects instrumental variable estimates for the probability to die within one to four years for male civil servants (difference-in-difference)*

\begin{tabular}{|c|c|c|c|c|c|c|c|c|}
\hline \multirow[b]{2}{*}{ The probability to die within } & \multicolumn{4}{|c|}{ Difference-in-difference } & \multicolumn{4}{|c|}{ Difference-in-difference-in-difference } \\
\hline & 1 year & 2 years & 3 years & 4 years & 1 year & 2 years & 3 years & 4 years \\
\hline $\mathrm{N}$ & 147,283 & 147,283 & 147,283 & 147,283 & $1,233,529$ & $1,233,529$ & $1,233,529$ & $1,233,529$ \\
\hline $\begin{array}{l}\text { Coefficient estimate } \\
\text { retirement }(\widehat{\omega})\end{array}$ & -0.017 & -0.022 & -0.023 & -0.028 & -0.017 & -0.022 & -0.023 & -0.029 \\
\hline P-value & 0.052 & 0.038 & 0.050 & 0.020 & 0.054 & 0.039 & 0.048 & 0.019 \\
\hline P-value J statistic & 0.553 & 0.182 & 0.702 & 0.388 & 0.545 & 0.179 & 0.702 & 0.386 \\
\hline $\begin{array}{l}\text { Fraction of total variation } \\
\text { explained by individual fixed }\end{array}$ & 0.387 & 0.656 & 0.730 & 0.777 & 0.388 & 0.650 & 0.729 & 0.774 \\
\hline
\end{tabular}

effects in second stage

* The models estimated here controls for lagged wage income, marital status, year fixed effects, nonlinear age effects and individual fixed effects. The p-values on the coefficient are based on heteroskedasticity robust standard errors. 
Table 8: Robustness checks on functional form*

\section{LATE estimates for Dif-in-dif Dif-in-Dif-in-Dif}

\begin{tabular}{llllll}
\hline Variation & & LATE & \multicolumn{1}{c}{ P-value } & \multicolumn{1}{c}{ LATE } & \multicolumn{1}{c}{ P-value } \\
\hline a. & FE IV 2nd, 3rd order age effects & -0.025 & 0.058 & -0.025 & 0.057 \\
b. & FE IV 2nd order age effects & -0.029 & 0.059 & -0.029 & 0.059 \\
c. & FE IV 2nd, 3rd, 4th order age effects & -0.025 & 0.067 & -0.025 & 0.067 \\
d. & FE IV for married workers only & -0.023 & 0.101 & -0.023 & 0.100 \\
e. & FE IV incl. lagged wage income partner & -0.023 & 0.101 & -0.019 & 0.110 \\
& and lagged retirement status partner & & & & \\
f. & FE IV for dataset incl. workers aged 52 & -0.025 & 0.043 & -0.026 & 0.042 \\
g. & FE IV for workers hospitalized before & -0.064 & 0.063 & -0.064 & 0.064 \\
& $\quad$ retirement only & & & & \\
h. & FE IV for dataset incl. workers & -0.029 & 0.024 & -0.028 & 0.024 \\
& hospitalized before retirement & & & &
\end{tabular}

Table 9: Random effects instrumental variable estimates for the probability to die within five years*

\begin{tabular}{|c|c|c|c|c|}
\hline \multirow[t]{2}{*}{ LATE estimates for } & \multicolumn{2}{|c|}{ Dif-in-dif } & \multicolumn{2}{|c|}{ Dif-in-Dif-in-Dif } \\
\hline & LATE & P-value & LATE & P-value \\
\hline RE IV & -0.031 & 0.010 & -0.031 & 0.013 \\
\hline
\end{tabular}

\begin{tabular}{lllll} 
& Statistic & P-value & Statistic & P-value \\
\hline Hausman test & 44.56 & 0.000 & 269.02 & 0.000
\end{tabular}

* The model estimated here controls for lagged wage income, marital status, year fixed effects, nonlinear age effects and individual fixed effects. The $p$-values are based on heteroskedasticity robust standard errors. 
Table 10: Hypothesized LATEs**

Probability to

die within

1 year

(Hypothesized)

coefficient

retirement $(\widehat{\omega})$

$-0.022$

$-0.023$

$-0.028$

$-0.025$

$-0.024$

$-0.019$

0.000

** These hypothesized LATES are used to make a back-of-the-envelope calculation on the amount of pension benefits that are paid extra due to retired civil servants living longer than civil servants who are not induced to retire by the introduction of the early retirement arrangement. 